\title{
Are cancer cells really softer than normal cells?
}

${ }^{1}$ Institut Curie, PSL Research University, CNRS, UMR 144, 26 rue d'Ulm F-75005, Paris, France

${ }^{2}$ Sorbonne Universités, UPMC University Paris 06, CNRS, UMR 144, 26 rue d'Ulm F-75005, Paris, France

+: to whom correspondence should be addressed (email: Jean-Baptiste.Manneville@curie.fr, phone: 331562465 64, fax: 331562464 21)

Running head: Mechanics of cancer cells

Keywords: microrheology, cancer, cytoskeleton, cell mechanics

\section{Summary}

Solid tumors are often first diagnosed by palpation, suggesting that the tumor is more rigid than its surrounding environment. Paradoxically, individual cancer cells appear to be softer than their healthy counterparts. In this review, we first list the physiological reasons indicating that cancer cells may be more deformable than normal cells. Next, we describe the biophysical tools that have been developed in recent years to characterize and model cancer cell mechanics. By reviewing the experimental studies that compared the mechanics of individual normal and cancer cells, we argue that cancer cells can indeed be considered as softer than normal cells. We then focus on the intracellular elements that could be responsible for the softening of cancer cells. Finally, we ask whether the mechanical differences between normal and cancer cells can be used as diagnostic or prognostic markers of cancer progression.

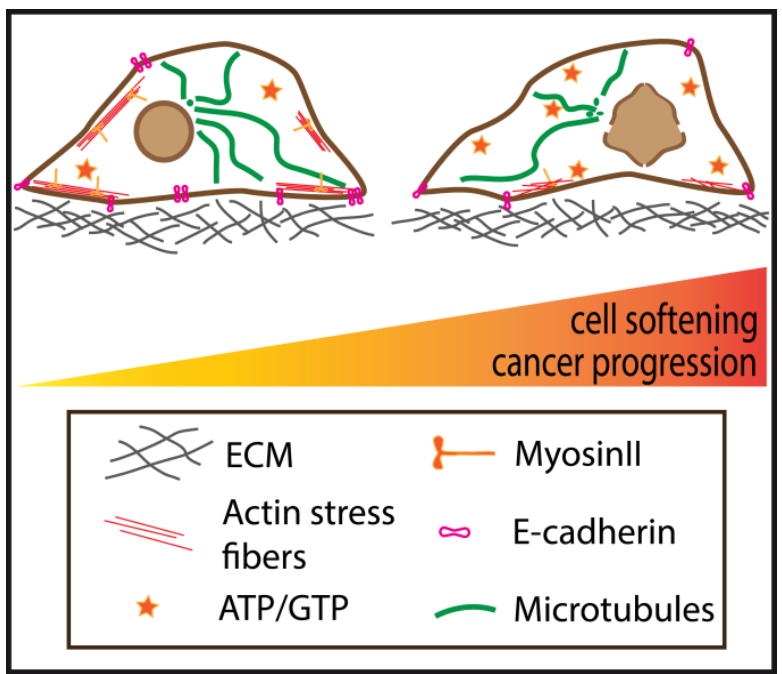


Most solid tumors are more rigid than their surrounding environment. In contrast, a growing number of studies show that individual cancer cells are more deformable than their healthy counterparts and that cell softening occurs during cancer progression. The mechanical differences between normal and cancer cells could be primarily due to modifications in the cytoskeleton, but other factors, such as the cell microenvironment, internal membrane trafficking or non-equilibrium active forces, may contribute.

\section{Contents}

Summary

1 Why may cancer cells be softer than normal cells? .....................................................................

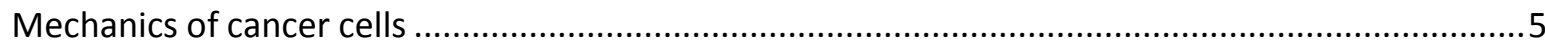

Microrheology of cancer cells: probing cellular rigidity at different scales....................................

Rheological parameters and theoretical modelling.....................................................................

2 Cancer cells really appear to be softer than normal cells..........................................................

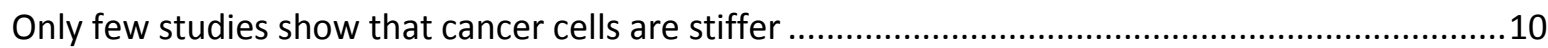

Mechanics of normal cells vs. cancer cells from the same organ...................................................10

Mechanics of normal cells vs. cancer cells from different organs ...................................................10

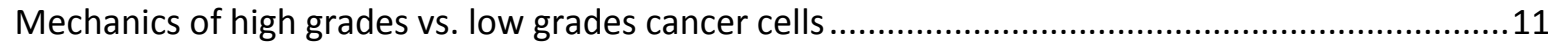

$3 \quad$ Why are cancer cells softer than normal cells? ......................................................................

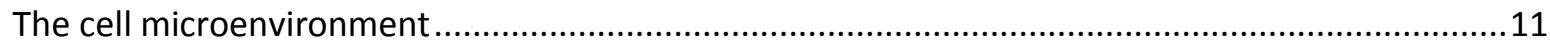

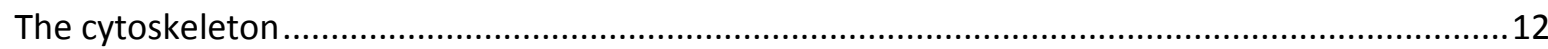

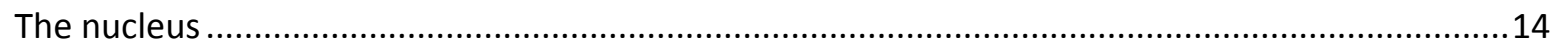

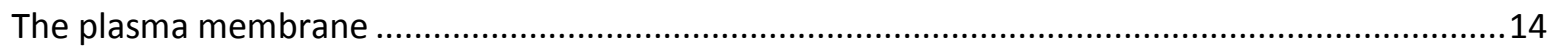

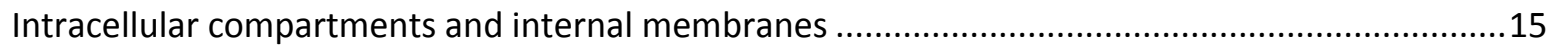

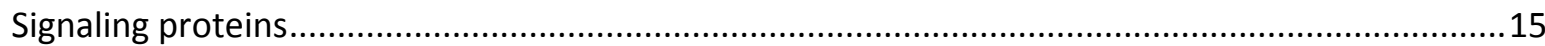

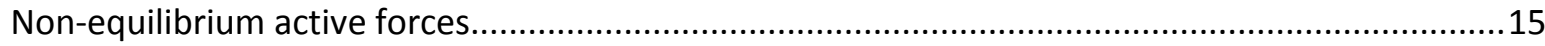

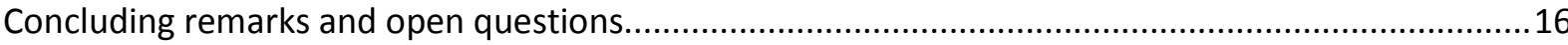

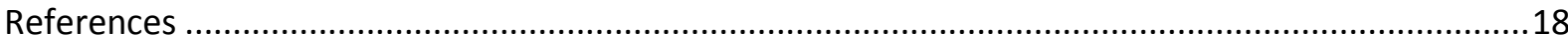

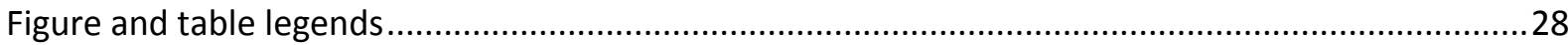

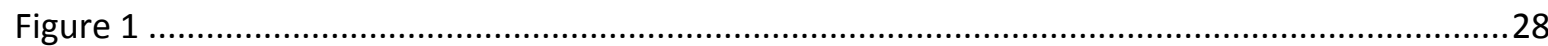

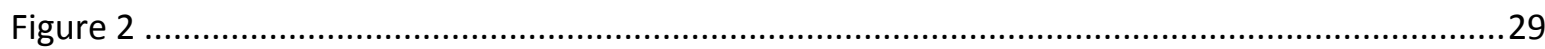


Figure 3 .

Table 1

Acknowledgements.

In the past ten years, the field of mechanobiology has received a growing interest. The number of reports describing techniques to probe cellular mechanics has risen steadily and a variety of theoretical models are now available to interpret experimental data. An emerging field in mechanobiology studies the physics of cancer cells. While molecular biology has produced a plethora of data on tumor biology, it still seems unable to clearly identify the fundamental differences between malignant and benign tumors. Physicists, with more reductionist and universal approaches, have asked whether changes in cell mechanics could be required for malignant transformation (Fritsch et al., 2010). Cells both exert forces on their surrounding environment and sense its mechanical properties. During all stages of tumor progression, from cell proliferation, to tumor development, invasion and metastasis, changes in both cellular and extra-cellular mechanics occur that participate to malignant transformation (Fritsch et al., 2010). As cancer progresses, tumor cells, or at least a subpopulation of cancer cells, appear to become softer (Fritsch et al., 2010). However, cancer cell softening remains a controversial issue. It is still not clear whether cancer cells all have the same material properties with softening being a universal feature or whether mechanical forces and features depend on the tumor type (Jonietz, 2012).

In this review, we focus on the mechanical differences between individual cancer and normal cells and ask whether these differences are significant enough to discriminate cancer cells from normal cells solely based on their mechanical properties (Mierke, 2014; Suresh, 2007 ; W. Zhang, Kai, Ueno, \& Qin, 2013). Individual cancer cell mechanics has been extensively studied in cancer cell lines and, to a lesser extent, in primary cells extracted from tumors, in either 2D or 3D in vitro assays. In situ mechanical measurements on whole organs or tumor tissues will not be discussed here, although studying cell mechanics in their native tumor environment is obviously relevant and may have a strong clinical impact (Fritsch et al., 2010). We define a 'normal' cell as a cell from the same organ as its cancer counterpart but from normal healthy tissue. In the case of cell lines, 'normal' cells, although they can proliferate, should not show any invasive or metastatic potential. In the case of primary cells, depending on the isolation and purification procedure, samples may be heterogeneous and contain cancer associated cells. We start by an inventory of the physiological factors that may account for a change in cellular mechanics during cancer development. We then review the experiments and theoretical models developed to measure cancer cell mechanics. Finally we try to identify which cellular elements are altered in cancer that could explain the observed mechanical differences with healthy cells.

\section{Why may cancer cells be softer than normal cells?}

Several, if not all, biological functions are altered in cancer cells during tumor progression. Hanahan and Weinberg have listed eight hallmarks of cancer which enable tumor growth and metastatic 
processes (Hanahan \& Weinberg, 2011). During the different steps of the disease, cancer cells acquire biological properties that cannot be found in normal cells. For instance, they have the capacity to replicate indefinitely and to exceed the predefined number of growth-and-division cycles. They can also resist cell death programmed by apoptosis, or evade growth suppressors by inactivating tumor suppressor genes which limit growth and proliferation (Hanahan \& Weinberg, 2011). Several signaling pathways, including those involved in membrane trafficking (Orgaz, Herraiz, \& Sanz-Moreno, 2014; Tzeng \& Wang, 2016), cell adhesion, polarity or migration (Asem, Buechler, Wates, Miller, \& Stack, 2016; Leve \& Morgado-Díaz, 2012), are deregulated during cancer due to overexpression or downregulation of key signaling molecules. Cell metabolism and energy consumption are also modified (Ghaffari, Mardinoglu, \& Nielsen, 2015).

One of the most striking phenomenon in cancer is metastatic spreading, leading to the appearance of secondary tumors in organs located far away from the primary tumor site (Valastyan \& Weinberg, 2011). During the metastatic process, the control of cell adhesion, polarity and migration is severely affected. Cancer cells first detach from the primary tumor, then enter the blood circulation by breaking through the basement membrane (intravasation) and survive there. Cancer cells then move out of the blood vessel (extravasation), and finally settle in targeted organs to initiate secondary tumors. Intravasation and extravasation are thought to be facilitated if cells are more deformable. Indeed it should be easier for soft, deformable cells to migrate through small gaps, crowded matrices or entangled matrix fibers, leading to the hypothesis along which the deformability of individual cancer cells should correlate with their metastatic potential.

But this may not be as simple as it seems. First, tumorous tissues are often detected by palpation because they are more rigid than the surrounding tissue. It is not clear whether this is due to cancer cells themselves or to the stroma. As shown by the Weaver group, stiffening of the stroma induces tumor rigidity and tumor progression (Levental et al., 2009), (Lu, Weaver, \& Werb, 2012) and promotes all hallmarks of cancer (Pickup, 2014). Cells are mechanosensitive and sense their microenvironment. Cells adapt to their environment in the long term by altering their genetic program (Butcher, Alliston, \& Weaver, 2009) but also respond very rapidly to environmental changes by modifying the cytoskeleton and its dynamics (Ananthakrishnan et al., 2006). Second, the epithelial-mesenchymal transition (EMT) and dedifferentiation modify the cell architecture, including the cytoskeleton and thus perturb cell mechanics. Third, since metastatic cells can also invade tissues locally or through the lymphatic circulation (see (Jin, Li, van Dam, Zhou, \& Zhang, 2016) for a recent review), a high deformability may not be required for efficient tumor spreading. Fourth, metastatic cells most often do not migrate as single cells but as a cohort during collective migration (Lintz, Muñoz, \& Reinhart-King, 2016) and only the so-called leader cells may be more deformable in order to facilitate the passage of more rigid follower cells. The stiffness of a cancer cell may also change according to the various microenvironments it encounters as it leaves the primary tumor, invades surrounding tissues and settles in a new secondary tumor (Kumar \& Weaver, 2009). Fifth, to divide in a stiff environment, cells have to overcome the pressure created by the rigid tumor. Confinement stresses were shown to inhibit cell division and proliferation in in vitro models (Alessandri et al., 2013; Delarue et al., 2014; Lancaster et al., 2013), suggesting that cancer cells must be stiff enough to divide.

In the next paragraphs, we summarize the physical and mechanical properties of cancer cells that correlate with their metastatic potential before focusing on the experimental techniques and theoretical models developed to study their rheology. 


\section{Mechanics of cancer cells}

The ability of cancer cells to create metastases is certainly the main reason why cancer cells were thought to be different from healthy cells, not only from a biological point of view but also from a mechanical point of view (Mierke, 2013). During metastasis, cancer cells sense and respond to the mechanical properties of their microenvironment, and generate forces thereon. Since the mechanotransduction events involved in cell movement and migration and their associated signaling pathways are altered during cancer cell transformation (Fernandez-Sanchez, Brunet, Röper, \& Farge, 2015), at least some of the mechanical properties of cancer cells could also be altered.

More than 25 years ago, Partin et al. showed with Fourier analysis that a high metastatic potential correlates with a high cell motility (Partin, Schoeniger, Mohler, \& S., 1989). Since then, many reports have shown a link between cell transformation and their migratory capacities both in $2 \mathrm{D}$ and in $3 \mathrm{D}$ in several types of cancer. For instance, high grade glioma cell lines are characterized by a faster and less directed 2D migration (Camand, Peglion, Osmani, Sanson, \& Etienne-Manneville, 2012). In bladder cancer cell lines, less invasive cells have smaller velocities (Agus et al., 2013; Kraning-Rush, Califano, \& Reinhart-King, 2012; Peschetola et al., 2013). In contrast, breast cancer cells exhibit a lower speed and a higher invasiveness in 1D and 3D, but not in 2D (Agus et al., 2013).

Cell-cell adhesion is regulated during EMT and invasion and the switch from E-cadherin to Ncadherin is characteristic of EMT (Le Bras, Taubenslag, \& Andl, 2012). Intuitively, reduced cell-cell adhesion should favor the spreading of cancer cells from the primary tumor (Cavallaro \& Christofori, 2001). In agreement, it was shown in an Atomic Force Microscopy (AFM) assay that breast cancer cells show lower cell-cell detachment forces than non-tumorogenic cells (Omidvar, TafazzoliShadpour, Shokrgozar, \& Rostami, 2014). However, recent results by Pawlizak et al. demonstrate that, in breast cancer cell lines, cell-cell adhesion does not correlate with cadherin density and that a tumorigenic cell line can have higher cell-cell adhesion than a non-tumorigenic cell line (Pawlizak et al., 2015). Theoretical work predicts that cell-cell adhesion induces cell motility in tissues through jamming and glass transitions $(\mathrm{Bi}, 2016)$. Another study showed that metastatic cells have a higher adhesion-related particle density than normal cells but also more numerous and smaller cell-matrix adhesion complexes (Rönnlund, Gad, Blom, Aspenström, \& Widengren, 2013) suggesting that cancer cells could have higher contractile forces than normal cells (Gad et al., 2012). Indeed invasiveness appears to correlate, at least in some cancer types, with contractile force generation (Mierke, Rösel, Fabry, \& Brábek, 2008).

Directly linked to contractile forces, traction forces have also been shown to be increased in cancer cells and to correlate with malignancy (Agus et al., 2013; Kraning-Rush et al., 2012; Peschetola et al., 2013) and invasiveness (Koch, 2012). However, conflicting results were obtained in murine breast cancer cell lines derived from the same primary tumor but possessing different metastatic potentials for which an increasing metastatic capacity correlates with a decrease in traction forces, a decrease in the 2D migration velocity and a decrease in cell adhesion (Indra et al., 2011). These results may be reconciled if the force-velocity curve is not monotonic, i.e. velocity increases with force at low traction forces then decreases at high traction forces. Even if, to our knowledge, such force-velocity relationships are not documented yet in the context of individual cancer cell motility, it was shown that the migration velocity of Dictyostelium discoideum decreases 
with increasing tractions forces due to solid friction (Rieu, Barentin, Maeda, \& Sawada, 2005). Similarly, in keratocytes, the force-velocity curves exhibits an optimum as a function of the lamellipodial pushing force (Heinemann, Doschke, \& Radmacher, 2011; Prass, Jacobson, Mogilner, \& Radmacher, 2006).

It is thus now well documented that motility, adhesion and contractility are altered in cancer cells leading in most cases to a reduced propensity to adhere to other cells and an increased ability to migrate individually or in small groups (Friedl \& Gilmour, 2009; Guan, 2015; J. A. Park, Atia, Mitchel, Fredberg, \& Butler, 2016). Our main goal here is to review the studies that have focused on the rheology of individual cancer cells and that have compared their rheological properties with those of normal cells. A growing number of experimental techniques are being used to study the mechanics of cancer cell lines or primary cells from biopsies. As we will argue below, the rheological data collected until now clearly point to a softening of cancer cells.

\section{Microrheology of cancer cells: probing cellular rigidity at different scales}

A large number of experimental tools have been developed to measure the rheology of complex materials. In the past twenty years, microrheology, i.e. rheology at the scale of the micrometer, has gained a lot of attention. Technologies have appeared to specifically measure the microrheology of cells in suspension or of adherent cells, at the scale of the whole cell or more local scales. Because we focus here on microrheology experimental studies that explicitly compare individual cancer cells with normal cells (for more general reviews on rheology and cell mechanics see for instance (Haase \& Pelling, 2015; Wirtz, 2009; Yao, Tassieri, Padgett, \& Cooper, 2009)), computational approaches (see (Katira et al., 2013) for a review) or techniques that have been used in the field of cell mechanics but not in the context of cancer are not detailed in the following. This is the case for instance of the uniaxial single cell microplate rheometer (Thoumine \& Ott, 1997b); (N. Desprat, 2006), the recent method using magnetic nanowires (Berret, 2016; Chevry, Colin, Abou, \& Berret, 2013) or acoustic microscopy (Nijenhuis, Zhao, Carisey, Ballestrem, \& Derby, 2014). Techniques that measure the stiffness of a tissue and do not resolve individual cells, such as ultrasound elastography (Chamming's et al., 2013; Tanter et al., 2008) or magnetic resonance elastography (MRE) (Pepin, Ehman, \& McGee, 2015) will also not be discussed in detail here. The strength of these techniques is to allow a non-invasive mechanical characterization of whole tumors and their surrounding tissues in vivo as opposed to the techniques we describe below. For instance, MRE has been used to probe several organs, such as breast, liver, brain or prostate. It was shown that malignant invasive breast tumors are about twice stiffer than benign breast lesions (Lorenzen et al., 2002). Similar results were obtained with liver or prostate tumors (Garteiser et al., 2012; S. Li et al., 2011; Venkatesh et al., 2008), confirming that tumor stiffening correlates with invasiveness. In contrast, a recent MRE study on intracranial tumors showed that tumorous tissues are softer than normal white matter and that grade IV glioblastomas multiforme are slightly softer than grade III anaplastic astrocytoma (ReissZimmermann et al., 2015).

Rheological techniques can be grouped according to the scale at which they measure cellular mechanics (Fig. 1). At the scale of the whole cell, mechanical parameters integrate the contribution of all cellular elements including potential matrix components, the plasma membrane and its 
associated cortex, the cytoskeleton, the nucleus, cytosolic constituents as well as intracellular membrane compartments. At more local scales, depending on the size of the probe used for the measure, only some specific cellular elements may contribute to the mechanical parameters. Micropipette aspiration (Lee \& Liu, 2014; Pachenari et al., 2014) or the so-called optical stretcher (Guck et al., 2005) fall in the first category. With these devices, cells in suspension are required. Because a mechanical stretch is applied on the cells, the actin cortex probably contributes predominantly to the extracted physical parameters. Microfluidics devices consisting of microchannels inside which cells have to enter and flow have also been developed to investigate the deformability of normal and cancer cells at the whole cell level (Byun et al., 2013; Hou et al., 2009).

Devices in the second category measure cell rheology of adherent cells by imposing a local deformation (strain) or a force (stress) either extracellularly or intracellularly. Techniques based on AFM have now become widely used and provide measurements of the elastic modulus of a region of interest on the plasma membrane by indenting a probe located at the extremity of the AFM cantilever (see (Mackay \& Kumar, 2013; Okajima, 2012); (Lekka et al., 2012) for reviews). Probes of a few 10-70 nanometers in diameter explore very local scales (Cross, Jin, Rao, \& Gimzewski, 2007; Lekka et al., 1999; Y. Li, Schnekenburger, \& Duits, 2009; Plodinec et al., 2012; Prabhune, Belge, Dotzauer, Bullerdiek, \& Radmacher, 2012; Rother, Nöding, Mey, \& Janshoff, 2014), but in other studies, micron-sized beads or cells have also been used as tip probes (Bastatas et al., 2012; Darling, Zauscher, Block, \& Guilak, 2007; Grady, Composto, \& Eckmann, 2016; Ketene, Schmelz, Roberts, \& Agah, 2012; Omidvar et al., 2014; S. Park, Koch, Cardenas, Käs, \& Shih, 2005; Xu et al., 2012). Similar to AFM-based techniques, indentation of magnetic beads localized on the cell surface using a magnetic field has been used to characterize ovarian cancer cell lines (Swaminathan et al., 2011). In both AFM and magnetic bead indentation, the mechanical measurements are dominated by the rigidity of the plasma membrane and the cortical actin cortex. In contrast, intracellular microrheology quantifies the mechanical properties of the cell interior and the contribution of intracellular elements, including cytoskeletal elements, membrane organelles and soluble components of the cytosol, at typical scales below a few micrometers. Passive intracellular microrheology is performed by tracking the movement of endogenous vesicles or granules or of an external probe internalized inside the cell by endocytosis, microinjection or ballistic injection (Tseng, Kole, \& Wirtz, 2002; Wirtz, 2009; Wu et al., 2012; Yamada, Wirtz, \& Kuo, 2000). As an example, passive rheology has been used in combination with AFM to characterize breast and pancreas cancer cells (Y. Li et al., 2009). In active intracellular microrheology, a force is applied on the same endogenous or exogenous probes and the resulting movement of the probe is monitored. The force is most often generated by optical or magnetic tweezers and is typically in the pico- to nano-Newton range. Several recent applications have been developed in the field of cancer (Berret, 2016; Guet et al., 2014; Guo et al., 2013).

\section{Rheological parameters and theoretical modelling}

Generic terms such as 'soft', 'rigid' or 'deformable' are often used to characterize cell mechanics, even if they do not represent any actual rheological parameter. In the field of rheology, a variety of physical parameters can be measured experimentally, depending on the experimental protocol and the model with which the experiments are interpreted. The two experimental observables are the stress, defined as the force applied on the material over a given cross section area (unit $\mathrm{Pa}$ ), and the 
(dimensionless) strain, defined as the deformation of the stressed material relative to a typical length scale of the system (Fig. 2A). Experimentally, either the strain under a given stress (the socalled creep experiment) or the stress under a given strain (the so-called stress relaxation experiment) can be measured to yield the visco-elastic properties of the material (Fig. 2B).

Visco-elastic materials show behaviors typical of both elastic solids and viscous fluids (Fig. 2C). A hookean elastic solid is characterized by its spring constant $K$ (in $N / m$ ) or its Young modulus $E$ $(\mathrm{Pa})$ and can deform instantly. The strain is proportional to the applied stress. A viscous Newtonian fluid is characterized by its viscosity $\eta$ (Pa.s) and can flow and undergo unlimited deformation. The flow, i.e. the time derivative of the strain, is proportional to the applied stress. A visco-elastic material responds to deformation both as an elastic solid and a viscous fluid with the ability to deform rapidly and to flow. The ratio between the viscosity and the Young modulus yields a time constant $\tau=\eta / E$ called the relaxation time is used to determine at which time scales the viscoelastic fluid behaves more as a fluid or as a solid. Depending on the mode of deformation, different mechanical moduli can be extracted. If a shear stress is applied (the force is parallel to the cross section), the complex shear modulus $G$ or the creep compliance $J=1 / G$ of the material is measured (Fig. 2A-B). If an extension or a compression stress is applied (the force is normal to the cross section), the Young modulus $E$ of the material is measured. The Young modulus relates to the elasticity of the material, while the complex shear modulus $G=G^{\prime}+i G^{\prime \prime}$ contains information on both elasticity and viscosity as its real part $G^{\prime}$ is related to elastic energy storage and its imaginary part G" is related to viscous energy loss.

Creep or stress relaxation experiments typically yields data in the time domain that have been analyzed using classical viscoelastic models based on the association of a finite number of dashpots and springs. The simplest models associate one spring and one dashpot either in series (Maxwell model) or in parallel (Kelvin-Voigt model). The expected responses of a visco-elastic fluid following these models in a creep experiment are represented in Figure 2C. Models associating more springs and dashpot have also been proposed, such as the Standard Linear Liquid (SLL) -also called the Jeffrey model- or the Standard Linear Solid (SLS) models (Swaminathan et al., 2011); (G. Zhang, Long, Wu, \& Yu, 2002); (Darling et al., 2007); (Pachenari et al., 2014). Fitting the data gives the values of the spring constants (in $\mathrm{N} / \mathrm{m}$ ) and of the viscosities (in Pa.s) corresponding respectively to the springs and dashpots included in the model. Depending on the number of dashpots and springs, several relaxation times can be calculated as $\tau_{i, j}=\eta_{i} / E_{j}$. Obviously, the quality of the fits increases with the number of viscoelastic elements. However, models with a finite number of relaxation times appear to be too simple to describe cell rheology and models with a continuous distribution of time constants that lead to power-law behaviors have been proposed as described below.

In active microrheology techniques in which an oscillating stress is applied at different frequencies, for instance with the uniaxial rheometer or optical tweezers, the frequency dependence of the complex shear modulus $G(\omega)$ is measured. It is now widely accepted that $G(\omega)$ follows a weak power-law $\mathrm{G}(\omega)=\mathrm{A} \omega^{\alpha}$ (Desprat, Richert, Simeon, \& Asnacios, 2005; Fabry et al., 2001) both at the whole cell scale and at intracellular local scale, independently of the experimental technique or the cell type (Balland et al., 2006). Still, one study in a hepatocyte carcinoma cell line (Hep G2) shows that a power-law cannot describe well the solid behavior of the cell at low frequencies (B. Wang et al., 2013). Several theoretical models of cell rheology predict that $G(\omega)$ should follow a power-law. In the poroelasticity model, the cell cytoplasm is a biphasic material made of a porous elastic meshwork in a fluid obeying a power law at long time scales 
(Moeendarbary et al., 2013). Similarly, power-law stems from soft glassy materials (Kollmannsberger \& Fabry, 2009). Even if some reservations have been expressed concerning specific aspects of the soft glassy model (Mandadapu, Govindjee, \& Mofrad, 2008; Stamenović et al., 2007), this model is viewed as one of the best to describe cell rheology accurately. A power-law behavior is the signature of a continuous distribution of time constants and cannot arise from discrete models consisting of a finite number of elements. Accordingly, the tensegrity (tensional integrity) model which consists of modelling the cytoskeleton as a stabilized network of prestressed rods ((N. Wang et al., 2001) does not predict the observed power-law dependence of $G(\omega)$ (Ingber, Wang, \& Stamenovic, 2014)).

Despite the popularity of viscoelastic models and power-law models, in some experimental techniques, cell rheology can also be measured independently of any model using one or several parameters specific to the experimental technique. For instance, the deformability rate was defined in optical stretcher experiments to quantify cell deformability (Guck et al., 2005). The entry time into microchannels is measured in microfluidics devices (Hou et al., 2009). A so-called rigidity index has been introduced to quantify relaxation experiments using optical tweezers (Guet et al., 2014; Mandal, Asnacios, Goud, \& Manneville, 2016). One drawback here is that knowing how the new parameters relate to the Young modulus and/or to the complex shear modulus is not trivial. In any case, cells are complex materials and it seems difficult to describe their mechanics only with a few moduli (Ananthakrishnan et al., 2006). Since several concurrent models are available to analyze the data, one remaining question is how to choose a 'good' model. Of course, the fits performed with the chosen model should adjust the data well, given the experimental errors, on the largest time, frequency and length scales. A 'good' model should also have a small number of free parameters. Because there are only two adjustable parameters in a power-law model (the prefactor $A$ and the exponent $\alpha$ ), power-laws have become increasingly popular. To compare the quality of different models to describe the data, some recent studies have used more than one model in their analysis (Chan et al., 2015; Lim, Zhou, \& Quek, 2006). In the following, the terms 'soft' or 'deformable' will be used to qualify cellular materials of low elasticity and/or low viscosity hence low values of the Young modulus or of the shear modulus.

\section{Cancer cells really appear to be softer than normal cells}

Palpation is often the first and simplest way to detect a tumor, for instance in breast tissues, before a more reliable diagnosis by biopsy. It is well accepted that tumor tissues, at the scale of the whole organ, are stiffer than their normal surrounding environment. Working with entire mammary gland, Levental et al. showed that the elastic modulus of the tissue indeed increases with tumorigenesis (Levental et al., 2009). However, at the level of the single cell, as discussed above, several lines of evidence suggest that cell stiffness should decrease as a normal cell transforms into a cancer cell. In this section, we review the studies comparing the mechanical properties of cancer cells and normal cells. To our knowledge, very few studies showed that cancer cells may be stiffer than normal cells (see below). The large majority of experiments, whether comparing cells from different organs, from the same organs or even comparing cancer cells of different grades, indicate that cancer cells are softer than normal cells and that cellular rigidity decreases with the progression of the disease. 


\section{Only few studies show that cancer cells are stiffer}

The first study showing a potential stiffer behavior of cancer cells was made in hepatocellular carcinoma cells (G. Zhang et al., 2002). The authors show that hepatocellular carcinoma cells have higher elastic constants than hepatocytes. However, they appear to have a lower viscosity. Moreover, working with cancer prostate cell lines, Bastatas et al. showed that low grade metastatic cells have higher elastic moduli than highly metastatic cells (Bastatas et al., 2012). Less strikingly, Li et al. worked with two cell lines of different grades derived from one human pancreas adenocarcinoma (Y. Li et al., 2009). Using AFM, no significant differences in the Young modulus between both cell lines was found whereas a larger mean squared displacement (MSD) was measured for the malignant cell line using passive intracellular microrheology. These are the only papers we know of where cancer cells appear to be more rigid than healthy cells, even if the results are not always statistically very significant. All the other studies focusing on individual cells show that cancer cells are softer than healthy cells.

\section{Mechanics of normal cells vs. cancer cells from the same organ}

Most studies in the field have been conducted with breast cancer cells (Agus et al., 2013; Guo et al., 2013; Hou et al., 2009; Y. Li et al., 2009). Fibroblasts (Thoumine \& Ott, 1997a) ; (Wottawah et al., 2005); (S. Park et al., 2005), hepatoma cell lines (G. Zhang et al., 2002), prostate cancer cells (Faria et al., 2008), kidney cell lines (Rebelo, de Sousa, Mendes Filho, \& Radmacher, 2013) and bladder cancer cells (Bertseva et al., 2012; Lekka et al., 1999) have also been studied. Cell lines from patients with primary oral or thyroid cancer were used for the first time to our knowledge by Remmerbach et al. (Remmerbach et al., 2009) and Prabhune et al. (Prabhune et al., 2012) respectively. Together, these results obtained with different techniques, indicate that the Young modulus and the spring constant of tumor cells are lower than those of normal cells and that in a large majority of cases, elastic storage (G') dominates over viscous loss (G') (see Table 1 ).

\section{Mechanics of normal cells vs. cancer cells from different organs}

Even if a relevant comparison of the mechanical properties of normal cells and cancer cells obviously requires comparing cells from the same organ, some AFM studies compared normal and cancer cells originating from different organs and also found that cancer cells are softer and more deformable. The elastic moduli of three normal cell lines (dermal fibroblasts, chondrocytes, HUVECs) and two cancer cell lines (HT180 fibrosarcoma and HUH-7 hepatocellular carcinoma) were measured by Grady et al. (Grady et al., 2016). The data show that both cancer cells have a modulus below $0.5 \mathrm{kPa}$ while moduli of the normal cell lines are above $1.3 \mathrm{kPa}$. A similar trend was observed when pleural fluids of seven patients with suspected adenocarcinoma from different locations (lung, breast, pancreas, liver and kidney) were studied (Cross et al., 2007). Cytological examinations revealed that four patients were positive for metastatic malignant cells whereas the three others had negative results. The authors pooled the data collected from the seven samples representing 40 cells from tumor samples and 48 cells from normal samples. For cancer cells, a Gaussian fit showed that tumor cells have a mean Young modulus of about $0.5 \mathrm{kPa}$ while a log-normal fit indicated that normal cells have a modulus of about $2 \mathrm{kPa}$ (Cross et al., 2007). Interestingly the distribution of moduli in cancer cells seems to be narrower than in normal cells, suggesting a lower variability in cancer cells (Cross et al., 2007; Grady et al., 2016; Xu et al., 2012). 


\section{Mechanics of high grades vs. low grades cancer cells}

In order to correlate cell stiffness with malignancy, cell mechanics has been measured in different grades of cancer cells from the same type of cancer. Here again, breast cancer is the most examined cancer type (Gal \& Weihs, 2012; Guck et al., 2005; Omidvar et al., 2014; Swaminathan et al., 2011; $\mathrm{Xu}$ et al., 2012), but cell lines from other organs such as colon (Pachenari et al., 2014), ovaries (Ketene et al., 2012) or chondosarcomas (Darling et al., 2007) have also been investigated. The Young modulus and spring constants were shown to decrease with cell malignancy and the deformability rate in optical stretcher experiments increases (see Table 1), showing that cell stiffness inversely correlates with the progression of the disease. A similar behavior was found in primary cells (Plodinec et al., 2012; Swaminathan et al., 2011). Accordingly, cytoskeletal fluidity measured by magnetic twisting cytometry was also shown to increase with the metastatic potential in a variety of cancer cell lines and in cells transformed with oncogenes (Coughlin et al., 2013). However, one AFM study in prostate cancer cells measured a higher Young modulus in highly metastatic cells than in non-invasive cells (Faria et al., 2008).

To conclude, these results (summarized in Table 1) clearly indicate that, even if the absolute values of the mechanical moduli may vary significantly depending on the microrheology technique, cancer cells from a large number of different organs are softer than their normal counterparts. Moreover, with only a few exceptions (Darling et al., 2007; Faria et al., 2008), the decrease in stiffness in cancer cells correlates with their metastatic potential.

\section{Why are cancer cells softer than normal cells?}

As detailed above most reports show that individual cancer cells are softer than normal cells. We now try to identify which cellular elements could be involved in these mechanical changes (Fig. 3). The role of the extracellular environment and of the actin cortex in cell mechanics is well-known and has been reviewed previously (Fletcher \& Mullins, 2010; Handorf, Zhou, Halanski, \& Li, 2015; Salbreux, Charras, \& Paluch, 2012) but other cellular constituents could clearly contribute to the observed rheological differences. We focus here more on the intracellular elements that could explain why cancer cells appear to be softer than normal cells.

\section{The cell microenvironment}

For the last ten years, mounting evidence shows that the cell microenvironment influences cell behavior. In particular, cells sense the stiffness of the matrix (Lange \& Fabry, 2013). Several studies have shown that the matrix stiffness controls lineage specification of mesenchymal stem cells (Engler, Sen, Sweeney, \& Discher, 2006), fibroblast polarization (Prager-Khoutorsky et al., 2011), stress fiber orientation (Zemel, Rehfeldt, Brown, Discher, \& Safran, 2010) and ordering of the cytoskeleton from a fluid state on soft substrates to a more solid state on stiff substrates (Gupta et al., 2015). In the context of cancer, the tumor microenvironment also influences the behavior of tumor cells (Butcher et al., 2009; Handorf et al., 2015; Tee, Fu, Chen, \& Janmey, 2011). For instance, the mechanical properties of the extracellular matrix (ECM) plays an important role in the metastatic process as stiffening of the ECM was shown to promote growth and invasion of mammary tissues both in vivo and in culture (Levental et al., 2009). More interestingly in the context of tumor cell 
rheology, a 2D or 3D collagen-environment impacts on the intracellular rigidity of malignant cells (Baker, Bonnecaze, \& Zaman, 2009). In 3D, a higher matrix stiffness surrounding isolated prostate cancer cells leads to a decrease in the apparent elastic modulus which is an order-of-magnitude higher in 3D than in 2D (Baker et al., 2009). Stiffer 3D environments also promote integrin adhesion, cytoskeletal tension, actin stress fiber formation and cell growth via a signaling pathway involving ERK and ROCK in breast tumor cells (Paszek et al., 2005).

\section{The cytoskeleton}

The cytoskeleton is known to play a major role in cell mechanics (Fletcher \& Mullins, 2010; Salbreux et al., 2012). Several works comparing the stiffness of normal and cancer cells have thus investigated cytoskeletal organization in cancer cells and tried to correlate changes in the levels of expression of cytoskeletal proteins with the observed decrease in cell stiffness. Most studies have focused on the actin cytoskeleton, especially on the actin cortex at the plasma membrane and on actomyosin complexes, but interest in microtubules and intermediate filaments has also been growing rapidly in the past two decades.

\section{Actin}

Modifications of the actin cytoskeleton during the metastatic process are well described (Nürnberg, Kitzing, \& Grosse, 2011; Peckham, 2016; Vignjevic \& Montagnac, 2008). Notably the relative amount of filamentous actin (F-actin) and monomeric actin (G-actin), which indicates the level of actin polymerization, depends on the cell malignancy. However conflicting results have been reported which seem to be cell-type dependent. For instance, in colon cancer cell lines of different metastatic potential, Nowak et al. found that cancer cells derived from the cancerous parental cell line have less G-actin (Nowak, Krawczenko, Duś, \& Malicka-Błaszkiewicz, 2002), while the opposite result was observed in keratinocytes and an increase in the G-actin/total actin ratio with invasiveness and metastatic potential was measured (Katsantonis et al., 1994). Metastatic colon cancer cells appear to have increased actin levels (Pachenari et al., 2014). More significantly, the organization of the actin cytoskeleton appears to be different in cancer cells. In breast and ovarian cancer cells and in thyroid cells, the actin network is less dense and contains less stress fibers (Calzado-Martín, Encinar, Tamayo, Calleja, \& San Paulo, 2016; Gal \& Weihs, 2012; Ketene et al., 2012; Prabhune et al., 2012). Similar observations were made in metastatic MDA-MB-231 breast cancer cells plated on adhesive micropatterns to standardize their intracellular organization when compared to non-tumorigenic MCF-10A cells, with changes in actin organization correlating with a strong decrease in cell stiffness in the metastatic cell line (Mandal et al., 2016). Interestingly, disrupting actin filament polymerization in normal cells induces a decrease in cell stiffness but also reduces the variability of the mechanical measurements (Cai et al., 2013; Grady et al., 2016) as observed in cancer cells (Cross et al., 2007; Grady et al., 2016; Xu et al., 2012).

\section{Microtubules}

The role of microtubules in cell rigidity seems less clear than that of actin and, here again, could be cell-type dependent. Microtubule depolymerization by nocodazole only resulted in a slight increase in stiffness in a variety of normal and cancer cells (Grady et al., 2016). A small but opposite effect of nocodazole was observed in retinal pigment epithelial (RPE-1) cells (Mandal et al., 2016) and in HeLa 
cells (Wilhelm, Gazeau, \& Bacri, 2003), while microtubule stabilization by taxol induced a clear increase in stiffness in RPE-1 cells (Mandal et al., 2016). Even if overexpression of $\beta 3$ tubulin correlates with tumor malignancy and resistance to chemotherapeutic drugs (Ferrandina et al., 2006), whether this is due to a change in cell mechanics has not been investigated. The amount of microtubules relative to actin filaments differs in different grades of colon cancer cells but this difference seems to be due to the total amount of actin (Pachenari et al., 2014). The organization of the microtubule network in three breast cancer cell lines with different metastatic potential did not show any significant variations (Calzado-Martín et al., 2016). However, when non-tumorigenic MCF$10 \mathrm{~A}$ and metastatic MDA-MB-231 breast cancer cells were plated on adhesive micropatterns, subtle differences in microtubule distribution could be revealed with a more uniform and less intricate network in the metastatic cells (Mandal et al., 2016).

\section{Intermediate filaments}

There are six types of intermediate filaments (IFs) differentially expressed depending on the cell type and the IF proteins that compose the filaments. Among these proteins, vimentin, a type III IF protein, is a marker of the EMT and its level of expression increases in cancer cells (Ngan et al., 2007; Ye et al., 2016). IFs have been shown to participate to cell mechanics (Block, Schroeder, Pawelzyk, Willenbacher, \& Köster, 2015; Charrier \& Janmey, 2016). In particular, knocking-out vimentin in mouse embryonic fibroblasts was shown to decrease cell stiffness (Guo et al., 2013). This seems contradictory to the numerous results we mentioned above showing a decrease in cell stiffness in cancer cells. However, the situation is probably more complex than it seems and correlating the amount of IF proteins with cell rigidity is difficult. For instance, by measuring the vimentin levels in different cancer cells lines, Swaminathan et al. reported that stiffer cancer cell lines express less vimentin than compliant cell lines (Swaminathan et al., 2011). In breast cancer cells, vimentin is not expressed in normal M10 and non-metastatic MCF-7 cancer (less deformable) cells, while highly metastatic MDA-MB-231 (more deformable) cells have high endogenous levels of vimentin (C. Y. Liu, Lin, Tang, \& Wang, 2015). However, reducing the amount of vimentin in MDA-MB-231 cells decreases cell stiffness while overexpressing vimentin in MCF7 cells increases cell stiffness (C. Y. Liu et al., 2015) as expected if vimentin IFs contribute to cell stiffness.

Similarly to vimentin, keratin IF proteins are involved in cell mechanics and their expression is modified during EMT. The 54 keratins are type I and type II IF proteins. The levels of keratin proteins are downregulated in carcinoma during EMT in epithelial cancers (Savagner, 2010). In breast cancer cell lines, high tumor grade was associated with a loss of cytokeratin and expression of vimentin (Willipinski-Stapelfeldt et al., 2005). Like vimentin, keratins have been used as diagnosis markers of cancer (Karantza, 2011). Most cancer cells are keratin-positive, but different keratins are expressed depending on the tumor type. For instance, colorectal adenocarcinomas appear to be K20+/K7- while malignant salivary gland carcinomas are K7+/K20- (Karantza, 2011). Downregulation of keratin during EMT may play a role in cancer cell softening. In keratinocytes lacking the entire keratin cytoskeleton, optical stretcher experiments demonstrate a clear increase in cell deformability that correlates with increased invasiveness (Seltmann, Fritsch, Käs, \& Magin, 2013). The spatial organization of keratin filaments also seems to play a major role. In pancreatic tumor cell lines, the keratin IF network is reorganized in the perinuclear region which induces a decrease in the elastic modulus (Suresh et al., 2005). 
Even if vimentin and keratins are involved in cancer cell mechanics, their exact roles and how they are related are not entirely clear yet. Since both keratin depletion (Seltmann et al., 2013) and vimentin depletion (Guo et al., 2013) induce cell softening while vimentin is expressed and keratins are downregulated during EMT, it is not obvious that cells should soften during EMT. Moreover in human melanoma cell lines, in contrast with the classical picture, vimentin and keratin appear to coexpress and the level of coexpression correlates with invasiveness (Hendrix M. J. C. \& 1992). Similarly, patients with breast tumors expressing both keratin and vimentin in similar amounts have poorer prognosis and survival rates (Thomas et al., 1999). It is very probable that IF proteins from other classes will be identified as contributing to cell stiffness. The class $V$ nuclear lamins in particular are known to contribute to nuclear mechanics (see below). Since IFs are heteropolymers and bundle within the cell, compensation mechanisms between the different IF proteins may play a role in mechanics when the expression of IF proteins is modified.

\section{The nucleus}

At the scale of the whole cell, the nucleus is a major organelle contributing to cell mechanics (Zwerger, Ho, \& Lammerding, 2011). As an example, the deformability of the nucleus is the limiting factor when cells migrate through tight constrictions (Lautscham et al., 2015; McGregor, Hsia, \& Lammerding, 2016; Raab et al., 2016). In cancer cells, the nucleus morphology is altered compared to healthy cells (Denais \& Lammerding, 2014). The volume of the nucleus is larger and its shape is more irregular. The expression of nuclear envelope proteins such as lamins is modified leading to breakage of the nuclear envelope (Bell \& Lammerding, 2016; Davidson \& Lammerding, 2014). Together these modifications of the nucleus could contribute to the decrease in stiffness observed in cancer cells and could facilitate the migration of cancer cells through narrow pores in the ECM.

\section{The plasma membrane}

The bending rigidity of the plasma membrane could contribute to the overall cell stiffness. The rigidity of the plasma membrane is controlled by its lipid composition and lipid synthesis and metabolism are known to be implicated in tumor development (Baenke, Peck, Miess, \& Schulze, 2013). More than twenty years ago, Mittelman et al. showed a correlation between the metastatic potential of lymphoma derived cell lines and their bending rigidity through measurements of membrane shape fluctuations (Mittelman, Levin, Verschueren, Debaetselier, \& Korenstein, 1994). Fluctuations were larger in cell lines with the highest metastatic potential. Supposing that fluctuations are of thermal origin, larger fluctuations indicate a lower rigidity in the highly metastatic cells. Softening of the plasma membrane was also reported recently in breast and cervical cancer cells using fluctuation analysis of membrane blebs or of giant plasma membrane vesicles (Händel et al., 2015). Conversely a pharmacological inhibitor that increases membrane rigidity also decreases invasiveness of a mammary carcinoma cell line (Braig et al., 2015). Interestingly, thermal noise is not the only source of membrane shape fluctuations and active non-equilibrium energy-dependent forces are thought to enhance such fluctuations (Betz, Lenz, Joanny, \& Sykes, 2009; Boss et al., 2012; Manneville, 1999; Tuvia, Levin, Bitler, \& Korenstein, 1998). A softening of the plasma membrane in metastatic cancer cells could thus also be due to a higher non-equilibrium activity. 


\section{Intracellular compartments and internal membranes}

Besides the nucleus, other intracellular compartments could also participate in intracellular rigidity. It was shown for instance that the local intracellular stiffness increases in the proximity of the Golgi apparatus (Guet et al., 2014). Moreover, dispersion of Golgi membranes by brefeldin-A has recently been reported to slightly increase intracellular rigidity (Mandal et al., 2016). Interestingly, similarly to experiments performed at the scale of the whole cell (Bonakdar et al., 2016), when a stress is applied on the Golgi apparatus, this organelle does not relax back to its original shape and actin contributes to its rheology (Guet et al., 2014). To date no other data directly support a role for intracellular compartments in cell mechanics, but given the cytosolic abundance of internal membranes from the endoplasmic reticulum, the endosomal or lysosomal compartment or the mitochondrial networks, it would be surprising that internal membranes do not significantly contribute to intracellular stiffness (Ohashi, Hagiwara, Bader, \& Knight, 2006). Since several signaling pathways involving membrane trafficking or mitochondria are affected during cancer cell transformation (Fehrenbacher \& Jäättelä, 2005; Goldenring, 2013; Kamp, Shacter, \& Weitzman, 2011; X. Wang, Peralta, \& Moraes, 2013), internal membranes may also be implicated in the decrease in cancer cell stiffness.

\section{Signaling proteins}

The interplay between cellular rigidity and the signaling pathways associated with the cytoskeleton and membrane trafficking is complex. From a fundamental point of view, understanding the modifications in cell rigidity in cancer cells could help identifying which signaling pathways or proteins are involved during tumorigenesis. For example, it has been shown that ROCK-dependent modifications of the keratin network play a role in cell stiffness (Bordeleau, Myrand Lapierre, Sheng, \& Marceau, 2012). Another example is given by the adhesion protein E-cadherin, an epithelial marker which levels differ in healthy and cancer cells. Breast highly invasive MDA-MB-231 (softer) cancer cells do not express E-cadherin but express N-cadherin instead, while non-invasive MCF-7 and slightly invasive T470 (stiffer) cell lines exhibit E-cadherin levels that inversely correlate with their invasiveness (Omidvar et al., 2014). A similar correlation was observed in ovarian cancer cell lines with less invasive, stiffer cells expressing more E-cadherin (Swaminathan et al., 2011).

\section{Non-equilibrium active forces}

In recent years, the role of active forces, such as the forces exerted by ATP-consuming molecular motors, in cell mechanics has attracted a lot of attention. From a statistical physics point of view, because they require an energy source, these out-of-equilibrium forces are of a different nature from thermal passive forces. Recently, a new technique based on optical tweezers called Force Spectrum Microscopy has been introduced to measure the effect of fluctuating forces caused by active processes on the cytoplasm rheology (Guo et al., 2014). Using this technique, the authors confirmed that malignant breast cancer cells (MCF-7 and M6C cells) have a softer cytoplasm than benign cells (MCF-10A and M28 cells) and that this decrease in stiffness correlates with higher intracellular forces, suggesting that non-equilibrium active forces may be enhanced in cancer cells. In cancer cells, ATP is predominantly produced by glycolysis rather than by mitochondria as it is the case for normal cells (Hanahan \& Weinberg, 2011). However the link between ATP-dependent forces and cell rigidity is not clear and conflicting results have been reported. Optical tweezers active microrheology using $0.5 \mu \mathrm{m}$ diameter beads oscillating in the $0.1-100 \mathrm{~Hz}$ frequency range has shown 
that ATP depletion softens the cell interior about two-fold (Guo et al., 2014), while an opposite effect was measured with a protocol based on the relaxation of $2 \mu \mathrm{m}$ diameter beads within an optical trap (Mandal et al., 2016). The last result is consistent with the lower tracer particle displacement and lower intracellular forces measured in the absence of ATP (Guo et al., 2014). The influence of myosin II activity on cancer cell mechanics was investigated more specifically by inhibiting myosin II with blebbistatin or downregulating myosin II. In adherent ovarian cancer cells and melanoma cells, blebbistatin decreases intracellular stiffness and increases invasiveness (Guo et al., 2014; Swaminathan et al., 2011). In contrast, a recent study in a variety of cells in suspension shows that myosin II inhibition increases cell stiffness measured by optical stretcher experiments (Chan et al., 2015), pointing to a central role of cell adhesion components, such as focal adhesions, or actin stress fibers, in controlling cell stiffness.

\section{Concluding remarks and open questions}

Most studies which have compared the mechanics of individual normal and cancer cells have found that cancer cells are softer than healthy cells. More importantly, the decrease in stiffness seems to correlate with the progression of the disease. Cell rigidity is not the only physical parameter that is modified in cancer cells. Cell adhesion, traction forces or internal tensile stresses are also affected. The mechanical properties of cancer cells could thus be used as novel diagnostic and/or prognostic markers to complement histological exams and genetic phenotyping of the tumor. To achieve this aim, several technical limitations and conceptual issues will first have to be resolved.

First, studies in the field should now concentrate on primary tumor cells from patients to validate the use of cell mechanics as a relevant diagnosis or prognosis tool. Until now, most of the work has been performed in cancer cell lines, some of which were established several decades ago. The grade of a given cell line is evaluated based on the World Health Organization Classification ("World Health Organization Classification of Tumours," 2004). Even if this classification is regularly updated, the grades of some of the earlier cell lines, which have most often been deduced from histological observations, may no longer be accurate. Moreover cell culture conditions and the number of cell passages can induce cross-contaminations and genetic drifts, or even alter the mechanical properties of the cells (Prabhune et al., 2012; Torsvik et al., 2014). Primary cancer cells from biopsies should provide more relevant systems despite the possible technical difficulties in maintaining them in culture. In recent years, patient derived xenografts (PDX) and patient derived tumor cells (PDTC) have been increasingly used as validated models for different types of cancer (Cassidy, Batra, Greenwood, \& Bruna, 2016; Xie et al., 2015). In the field of cancer cell rheology, the next step clearly involves the use of such models. The dimensionality may also play a crucial role (Mak, Kamm, \& Zaman, 2014). Until now, most studies have been performed on suspended cells or on cells in 2D cultures. Efforts should now be directed towards rheological measurements on cells in a 3D environment.

However, since cells can adapt very rapidly to their environment, cell softening could be due to the fact that cells are studied in an artificial in vitro environment and not in their native tumor environment. As discussed above, cancer cell lines may have different properties from their original tumor cells due to their culture conditions. Patient-derived cells or cells obtained by fine needle 
aspiration from solid tumors are extracted from the primary tumor and transferred to a new environment. The mechanical parameters measured in vitro may thus not be representative of the mechanical state of the cells inside the tumor. However because significant differences are observed between normal and cancer cells, in vitro measurements could still be useful for diagnosis and/or prognosis. Cell softening seems also at odds with findings showing that tumor cells have a higher contractility and exert higher traction forces. But again, this may be induced by the stiffer tumor environment or depend on the type of cancer.

Even if the different microrheology techniques qualitatively give similar results by showing that cancer cells are softer than normal cells, the absolute values of the measured physical parameters appear to vary significantly, even between studies performed with the same instrument (Table 1). Measurements on suspended cells obtained with the optical stretcher or external measurements obtained with AFM may be dominated by the actin cortex and may not fully probe the internal cytoskeleton which is predicted to be more contractile in cancer cells. Associating several techniques, especially techniques operating at different scales, should help resolve this issue. For instance, AFM has been applied together with particle tracking (Agus et al., 2013; Y. Li et al., 2009) or with acoustic microscopy (Nijenhuis et al., 2014). The variability of the measurements is mostly due to variability in cell morphology, for instance cell size or volume, spread area of adherent cells, positioning of intracellular organelles or nucleus size. This is particularly true for techniques that operate at local scales. For example, the results of AFM experiments not only strongly depends on the zone which is probed in the cell, but also on the cell shape and on the geometry of the probe tip used for indentation (Darling et al., 2007). To standardize cell geometry and organization, adhesive micropatterns have been combined with AFM (Mandal et al., 2016; Rigato, Rico, Eghiaian, Piel, \& Scheuring, 2015) or with optical tweezers microrheology (Mandal et al., 2016; Rigato et al., 2015). Micropatterning allows a better reproducibility of the experiments but requires a fine tuning of the cell aspect ratio (volume/surface) with the micropattern area to ensure meaningful intracellular mechanical measurements. The temperature is also a critical parameter in rheological experiments. Cell heating in optical tweezers has been known for a long time (Y. Liu et al., 1995) but has recently been used in thermorheology experiments based on an optical stretcher to assess the mechanical parameters of breast cancer cells (Kießling, Stange, Kas, \& Fritsch, 2013; Schmidt et al., 2015).

There are several requisites for an efficient diagnostic method for cancer. First, techniques requiring a low amount of tissue or ideally allowing in situ diagnosis are highly advantageous. Time is also an important factor and measurements and subsequent data analyses should be fast. Finally, the technique should yield statistically significant data. When working with individual cells, large ensemble statistics can be obtained with high throughput methods. High-throughput analysis of cell rheological properties has been comprehensively reviewed recently (Darling \& Di Carlo, 2015; Weaver et al., 2014). Microfluidic approaches and optical-tweezers based approaches are most amenable to high-throughput. Measurement of the transit time of cells through constrictions or channels combined with microfluidic flow (Byun et al., 2013; Hou et al., 2009; Lange et al., 2015) allows the analysis of 1-100 cells/s (Darling \& Di Carlo, 2015). Stretching cells using hydrodynamic stresses (Dudani, Gossett, Tse, \& Di Carlo, 2013) gives the highest analysis rates, up to 20000 cell/s. The optical stretcher has also recently been developed into a high-throughput technique with typically 1 cell/min to 1 cell/sec rates of measurement of cell deformability (Darling et al., 2007; Otto et al., 2015). Other approaches based on acoustic waves, osmotic shocks or automation of AFM have 
been devised (Darling \& Di Carlo, 2015) but their application to cancer cell mechanics remain limited. Of note, coupling standing acoustic wave with microfluidics showed that cancer cells of various origins are more compressible than normal cells (Hartono et al., 2011).

A limiting factor here may be tumor heterogeneity (Meacham \& Morrison, 2013). Differences not only exist between tumors of the same type in different patients, but also between cells within a tumor. For a given stage in cancer development, cells of different grades can coexist, depending on their localization within the tumor. Correlating with known genetic or epigenetic differences, mechanical differences may appear. Cells of the same grade could thus have different mechanical properties. Moreover, soft and stiff regions coexist in a tumor, as shown for instance by MRE (Pepin, Ehman, \& McGee, 2015), which may contain both soft and stiff cells and/or extracellular matrix. Even if malignancy seems to correlate with the decrease in cell stiffness, the tumor grade may not be the relevant parameter for a precise mechanics-based diagnosis. In this context, can cell rheology really lead to new diagnostic or prognostic methods for cancers? Clearly several technical challenges still remain to be overcome. However given the evident mechanical differences between normal and cancer cells, chances of success in a near future are high. From a fundamental point of view, understanding why cell mechanics is altered during cancer progression should also give extremely valuable information to better understand this disease.

\section{References}

*Agus, D. B., Alexander, J. F., Arap, W., Ashili, S., Aslan, J. E., Austin, R. H., . . Network, P. S.-O. C. (2013). A physical sciences network characterization of non-tumorigenic and metastatic cells. Sci Rep, 3, 1449. doi:10.1038/srep01449

Alessandri, K., Sarangi, B. R., Gurchenkov, V. V., Sinha, B., Kießling, T. R., Fetler, L., . . Nassoy, P. (2013). Cellular capsules as a tool for multicellular spheroid production and for investigating the mechanics of tumor progression in vitro. Proc Natl Acad Sci U S A, 110(37), 14843-14848. doi:10.1073/pnas.1309482110

Ananthakrishnan, R., Guck, J., Wottawah, F., Schinkinger, S., Lincoln, B., Romeyke, M., . . Käs, J. (2006). Quantifying the contribution of actin networks to the elastic strength of fibroblasts. J Theor Biol, 242(2), 502-516. doi:10.1016/j.jtbi.2006.03.021

Asem, M. S., Buechler, S., Wates, R. B., Miller, D. L., \& Stack, M. S. (2016). Wnt5a Signaling in Cancer. Cancers (Basel), 8(9). doi:10.3390/cancers8090079

Baenke, F., Peck, B., Miess, H., \& Schulze, A. (2013). Hooked on fat: the role of lipid synthesis in cancer metabolism and tumour development. Dis Model Mech, 6(6), 1353-1363.

doi:10.1242/dmm.011338

Baker, E. L., Bonnecaze, R. T., \& Zaman, M. H. (2009). Extracellular matrix stiffness and architecture govern intracellular rheology in cancer. Biophys J, 97(4), 1013-1021. doi:10.1016/j.bpj.2009.05.054

Balland, M., Desprat, N., Icard, D., Féréol, S., Asnacios, A., Browaeys, J., . . Gallet, F. (2006). Power laws in microrheology experiments on living cells: Comparative analysis and modeling. Phys Rev E Stat Nonlin Soft Matter Phys, 74(2 Pt 1), 021911. doi:10.1103/PhysRevE.74.021911 
Bastatas, L., Martinez-Marin, D., Matthews, J., Hashem, J., Lee, Y. J., Sennoune, S., . . Park, S. (2012). AFM nano-mechanics and calcium dynamics of prostate cancer cells with distinct metastatic potential. Biochim Biophys Acta, 1820(7), 1111-1120. doi:10.1016/j.bbagen.2012.02.006

Bell, E. S., \& Lammerding, J. (2016). Causes and consequences of nuclear envelope alterations in tumour progression. Eur J Cell Biol. doi:10.1016/j.ejcb.2016.06.007

Berret, J. F. (2016). Local viscoelasticity of living cells measured by rotational magnetic spectroscopy. Nat Commun, 7, 10134. doi:10.1038/ncomms10134

Bertseva, E., Grebenkov, D., Schmidhauser, P., Gribkova, S., Jeney, S., \& Forró, L. (2012). Optical trapping microrheology in cultured human cells. Eur Phys J E Soft Matter, 35(7), 63. doi:10.1140/epje/i2012-12063-4

Betz, T., Lenz, M., Joanny, J. F., \& Sykes, C. (2009). ATP-dependent mechanics of red blood cells. Proc Natl Acad Sci U S A, 106(36), 15320-15325. doi:10.1073/pnas.0904614106

Bi, D., Yang, X, Marchetti M. C., and Manning M. L. (2016). Motility-driven glass and jamming transitions in biological tissues. Physical Review X, 6. doi:10.1103/PhysRevX.6.021011

Block, J., Schroeder, V., Pawelzyk, P., Willenbacher, N., \& Köster, S. (2015). Physical properties of cytoplasmic intermediate filaments. Biochim Biophys Acta, 1853(11 Pt B), 3053-3064. doi:10.1016/j.bbamcr.2015.05.009

Bonakdar, N., Gerum, R., Kuhn, M., Spörrer, M., Lippert, A., Schneider, W., . . Fabry, B. (2016). Mechanical plasticity of cells. Nat Mater, 15(10), 1090-1094. doi:10.1038/nmat4689

Bordeleau, F., Myrand Lapierre, M. E., Sheng, Y., \& Marceau, N. (2012). Keratin 8/18 regulation of cell stiffness-extracellular matrix interplay through modulation of Rho-mediated actin cytoskeleton dynamics. PLoS One, 7(6), e38780. doi:10.1371/journal.pone.0038780

Boss, D., Hoffmann, A., Rappaz, B., Depeursinge, C., Magistretti, P. J., Van de Ville, D., \& Marquet, P. (2012). Spatially-resolved eigenmode decomposition of red blood cells membrane fluctuations questions the role of ATP in flickering. PLoS One, 7(8), e40667. doi:10.1371/journal.pone.0040667

Braig, S., Schmidt, B. U. S., Stoiber, K., Händel , C., Möhn , T., Werz, O., . . Vollmar , A. M. (2015). Pharmacological targeting of membrane rigidity: implications on cancer cell migration and invasion. New Journal of Physics, 17. doi:10.1088/1367-2630/17/8/083007

Butcher, D. T., Alliston, T., \& Weaver, V. M. (2009). A tense situation: forcing tumour progression. Nat Rev Cancer, 9(2), 108-122. doi:10.1038/nrc2544

Byun, S., Son, S., Amodei, D., Cermak, N., Shaw, J., Kang, J. H., . . Manalis, S. R. (2013). Characterizing deformability and surface friction of cancer cells. Proc Natl Acad Sci U S A, 110(19), 7580-7585. doi:10.1073/pnas.1218806110

Cai, P., Mizutani, Y., Tsuchiya, M., Maloney, J. M., Fabry, B., Van Vliet, K. J., \& Okajima, T. (2013). Quantifying cell-to-cell variation in power-law rheology. Biophys J, 105(5), 1093-1102. doi:10.1016/j.bpj.2013.07.035

Calzado-Martín, A., Encinar, M., Tamayo, J., Calleja, M., \& San Paulo, A. (2016). Effect of Actin Organization on the Stiffness of Living Breast Cancer Cells Revealed by Peak-Force Modulation Atomic Force Microscopy. ACS Nano, 10(3), 3365-3374. doi:10.1021/acsnano.5b07162

Camand, E., Peglion, F., Osmani, N., Sanson, M., \& Etienne-Manneville, S. (2012). N-cadherin expression level modulates integrin-mediated polarity and strongly impacts on the speed and directionality of glial cell migration. J Cell Sci, 125(Pt 4), 844-857. doi:10.1242/jcs.087668

Cassidy, J., Batra, A. S., Greenwood, W., \& Bruna, A. (2016). Patient derived tumour xenografts for breast cancer drug discovery. Endocr Relat Cancer. doi:10.1530/ERC-16-0251

Cavallaro, U., \& Christofori, G. (2001). Cell adhesion in tumor invasion and metastasis: loss of the glue is not enough. Biochim Biophys Acta, 1552(1), 39-45.

Chamming's, F., Latorre-Ossa, H., Le Frère-Belda, M. A., Fitoussi, V., Quibel, T., Assayag, F., . . . Fournier, L. S. (2013). Shear wave elastography of tumour growth in a human breast cancer 
model with pathological correlation. Eur Radiol, 23(8), 2079-2086. doi:10.1007/s00330-0132828-8

Chan, C. J., Ekpenyong, A. E., Golfier, S., Li, W., Chalut, K. J., Otto, O., . . Lautenschläger, F. (2015). Myosin II Activity Softens Cells in Suspension. Biophys J, 108(8), 1856-1869. doi:10.1016/j.bpj.2015.03.009

Charrier, E. E., \& Janmey, P. A. (2016). Mechanical Properties of Intermediate Filament Proteins. Methods Enzymol, 568, 35-57. doi:10.1016/bs.mie.2015.09.009

Chevry, L., Colin, R., Abou, B., \& Berret, J. F. (2013). Intracellular micro-rheology probed by micronsized wires. Biomaterials, 34(27), 6299-6305. doi:10.1016/j.biomaterials.2013.05.002

Coughlin, M. F., Bielenberg, D. R., Lenormand, G., Marinkovic, M., Waghorne, C. G., Zetter, B. R., \& Fredberg, J. J. (2013). Cytoskeletal stiffness, friction, and fluidity of cancer cell lines with different metastatic potential. Clin Exp Metastasis, 30(3), 237-250. doi:10.1007/s10585-0129531-z

Cross, S. E., Jin, Y. S., Rao, J., \& Gimzewski, J. K. (2007). Nanomechanical analysis of cells from cancer patients. Nat Nanotechnol, 2(12), 780-783. doi:10.1038/nnano.2007.388

Darling, E. M., \& Di Carlo, D. (2015). High-Throughput Assessment of Cellular Mechanical Properties. Annu Rev Biomed Eng, 17, 35-62. doi:10.1146/annurev-bioeng-071114-040545

Darling, E. M., Zauscher, S., Block, J. A., \& Guilak, F. (2007). A thin-layer model for viscoelastic, stressrelaxation testing of cells using atomic force microscopy: do cell properties reflect metastatic potential? Biophys J, 92(5), 1784-1791. doi:10.1529/biophysj.106.083097

Davidson, P. M., \& Lammerding, J. (2014). Broken nuclei--lamins, nuclear mechanics, and disease. Trends Cell Biol, 24(4), 247-256. doi:10.1016/j.tcb.2013.11.004

Delarue, M., Montel, F., Vignjevic, D., Prost, J., Joanny, J. F., \& Cappello, G. (2014). Compressive stress inhibits proliferation in tumor spheroids through a volume limitation. Biophys $J$, 107(8), 1821-1828. doi:10.1016/j.bpj.2014.08.031

Denais, C., \& Lammerding, J. (2014). Nuclear mechanics in cancer. Adv Exp Med Biol, 773, 435-470. doi:10.1007/978-1-4899-8032-8_20

Desprat, N., Richert, A., Simeon, J., \& Asnacios, A. (2005). Creep function of a single living cell. Biophys J, 88(3), 2224-2233. doi:10.1529/biophysj.104.050278

Dudani, J. S., Gossett, D. R., Tse, H. T., \& Di Carlo, D. (2013). Pinched-flow hydrodynamic stretching of single-cells. Lab Chip, 13(18), 3728-3734. doi:10.1039/c3lc50649e

Engler, A. J., Sen, S., Sweeney, H. L., \& Discher, D. E. (2006). Matrix elasticity directs stem cell lineage specification. Cell, 126(4), 677-689. doi:10.1016/j.cell.2006.06.044

Fabry, B., Maksym, G. N., Butler, J. P., Glogauer, M., Navajas, D., \& Fredberg, J. J. (2001). Scaling the microrheology of living cells. Phys Rev Lett, 87(14), 148102.

Faria, E. C., Ma, N., Gazi, E., Gardner, P., Brown, M., Clarke, N. W., \& Snook, R. D. (2008). Measurement of elastic properties of prostate cancer cells using AFM. Analyst, 133(11), 1498-1500. doi:10.1039/b803355b

Fehrenbacher, N., \& Jäättelä, M. (2005). Lysosomes as targets for cancer therapy. Cancer Res, 65(8), 2993-2995. doi:10.1158/0008-5472.CAN-05-0476

Fernandez-Sanchez, M. E., Brunet, T., Röper, J. C., \& Farge, E. (2015). Mechanotransduction's impact on animal development, evolution, and tumorigenesis. Annu Rev Cell Dev Biol, 31, 373-397. doi:10.1146/annurev-cellbio-102314-112441

Ferrandina, G., Zannoni, G. F., Martinelli, E., Paglia, A., Gallotta, V., Mozzetti, S., . . Ferlini, C. (2006). Class III beta-tubulin overexpression is a marker of poor clinical outcome in advanced ovarian cancer patients. Clin Cancer Res, 12(9), 2774-2779. doi:10.1158/1078-0432.CCR-052715

Fletcher, D. A., \& Mullins, R. D. (2010). Cell mechanics and the cytoskeleton. Nature, 463(7280), 485492. doi:10.1038/nature08908 
Friedl, P., \& Gilmour, D. (2009). Collective cell migration in morphogenesis, regeneration and cancer. Nat Rev Mol Cell Biol, 10(7), 445-457. doi:10.1038/nrm2720

Fritsch, A., Höckel, M., Kiessling, T., Nnetu, K. D., Wetzel, F., Zink, M., \& Käs, J. A. (2010). Are biomechanical changes necessary for tumour progression? Nature Physics, 6, 730-732.

Gad, A. K., Rönnlund, D., Spaar, A., Savchenko, A. A., Petranyi, G., Blom, H., . . Aspenström, P. (2012). Rho GTPases link cellular contractile force to the density and distribution of nanoscale adhesions. FASEB J, 26(6), 2374-2382. doi:10.1096/fj.11-195800

Gal, N., \& Weihs, D. (2012). Intracellular mechanics and activity of breast cancer cells correlate with metastatic potential. Cell Biochem Biophys, 63(3), 199-209. doi:10.1007/s12013-012-9356-z

Garteiser, P., Doblas, S., Daire, J. L., Wagner, M., Leitao, H., Vilgrain, V., . . Van Beers, B. E. (2012). MR elastography of liver tumours: value of viscoelastic properties for tumour characterisation. Eur Radiol, 22(10), 2169-2177. doi:10.1007/s00330-012-2474-6

Ghaffari, P., Mardinoglu, A., \& Nielsen, J. (2015). Cancer Metabolism: A Modeling Perspective. Front Physiol, 6, 382. doi:10.3389/fphys.2015.00382

Goldenring, J. R. (2013). A central role for vesicle trafficking in epithelial neoplasia: intracellular highways to carcinogenesis. Nat Rev Cancer, 13(11), 813-820. doi:10.1038/nrc3601

Grady, M. E., Composto, R. J., \& Eckmann, D. M. (2016). Cell elasticity with altered cytoskeletal architectures across multiple cell types. J Mech Behav Biomed Mater, 61, 197-207. doi:10.1016/j.jmbbm.2016.01.022

Guan, X. (2015). Cancer metastases: challenges and opportunities. Acta Pharm Sin B, 5(5), 402-418. doi:10.1016/j.apsb.2015.07.005

Guck, J., Schinkinger, S., Lincoln, B., Wottawah, F., Ebert, S., Romeyke, M., ... Bilby, C. (2005). Optical deformability as an inherent cell marker for testing malignant transformation and metastatic competence. Biophys J, 88(5), 3689-3698. doi:10.1529/biophysj.104.045476

Guet, D., Mandal, K., Pinot, M., Hoffmann, J., Abidine, Y., Sigaut, W., . . Manneville, J. B. (2014). Mechanical role of actin dynamics in the rheology of the Golgi complex and in Golgiassociated trafficking events. Curr Biol, 24(15), 1700-1711. doi:10.1016/j.cub.2014.06.048

Guo, M., Ehrlicher, A. J., Jensen, M. H., Renz, M., Moore, J. R., Goldman, R. D., . . Weitz, D. A. (2014). Probing the stochastic, motor-driven properties of the cytoplasm using force spectrum microscopy. Cell, 158(4), 822-832. doi:10.1016/j.cell.2014.06.051

Guo, M., Ehrlicher, A. J., Mahammad, S., Fabich, H., Jensen, M. H., Moore, J. R., . . Weitz, D. A. (2013). The role of vimentin intermediate filaments in cortical and cytoplasmic mechanics. Biophys J, 105(7), 1562-1568. doi:10.1016/j.bpj.2013.08.037

Gupta, M., Sarangi, B. R., Deschamps, J., Nematbakhsh, Y., Callan-Jones, A., Margadant, F., .. . Ladoux, B. (2015). Adaptive rheology and ordering of cell cytoskeleton govern matrix rigidity sensing. Nat Commun, 6, 7525. doi:10.1038/ncomms8525

Haase, K., \& Pelling, A. E. (2015). Investigating cell mechanics with atomic force microscopy. $J$ R Soc Interface, 12(104), 20140970. doi:10.1098/rsif.2014.0970

Hanahan, D., \& Weinberg, R. A. (2011). Hallmarks of cancer: the next generation. Cell, 144(5), 646674. doi:10.1016/j.cell.2011.02.013

Handorf, A. M., Zhou, Y., Halanski, M. A., \& Li, W. J. (2015). Tissue stiffness dictates development, homeostasis, and disease progression. Organogenesis, 11(1), 1-15. doi:10.1080/15476278.2015.1019687

Hartono, D., Liu, Y., Tan, P. L., Then, X. Y., Yung, L. Y., \& Lim, K. M. (2011). On-chip measurements of cell compressibility via acoustic radiation. Lab Chip, 11(23), 4072-4080. doi:10.1039/c1lc20687g

Heinemann, F., Doschke, H., \& Radmacher, M. (2011). Keratocyte lamellipodial protrusion is characterized by a concave force-velocity relation. Biophys J, 100(6), 1420-1427. doi:10.1016/j.bpj.2011.01.063 
Hendrix M. J. C., S. E. A., Chu Yi-Wen, Seftor R. E. B., Nagle R. B., McDaniel K. M., Leong S. P. L., \&, Y. K. H., Leibovitz A. M., Meyskens F. L., Jr., Conaway D. H., Welch D. R., Liotta L. A., Stetler-Stevenson W. (1992). Coexpression of vimentin and keratins by human melanoma tumor cells: correlation with invasive and metastatic potential In (Vol. 84, pp. 165-174). Journal of the National Cancer Institute.

Hou, H. W., Li, Q. S., Lee, G. Y., Kumar, A. P., Ong, C. N., \& Lim, C. T. (2009). Deformability study of breast cancer cells using microfluidics. Biomed Microdevices, 11(3), 557-564. doi:10.1007/s10544-008-9262-8

Händel, C., Schmidt , B. U. S., Schiller ， J., Dietrich , U., Möhn ，T., Kießling ，T. R., ... Käs, J. A. (2015). Cell membrane softening in human breast and cervical cancer cells. New Journal of Physics, 17. doi:10.1088/1367-2630/17

Indra, I., Undyala, V., Kandow, C., Thirumurthi, U., Dembo, M., \& Beningo, K. A. (2011). An in vitro correlation of mechanical forces and metastatic capacity. Phys Biol, 8(1), 015015. doi:10.1088/1478-3975/8/1/015015

Ingber, D. E., Wang, N., \& Stamenovic, D. (2014). Tensegrity, cellular biophysics, and the mechanics of living systems. Rep Prog Phys, 77(4), 046603. doi:10.1088/0034-4885/77/4/046603

Jin, K., Li, T., van Dam, H., Zhou, F., \& Zhang, L. (2016). Molecular insights into tumour metastasis: tracing the dominant events. J Pathol. doi:10.1002/path.4871

Jonietz, E. (2012). Mechanics: The forces of cancer. Nature, 491(7425), S56-57.

Kamp, D. W., Shacter, E., \& Weitzman, S. A. (2011). Chronic inflammation and cancer: the role of the mitochondria. Oncology (Williston Park), 25(5), 400-410, 413.

Karantza, V. (2011). Keratins in health and cancer: more than mere epithelial cell markers. Oncogene, 30(2), 127-138. doi:10.1038/onc.2010.456

Katsantonis, J., Tosca, A., Koukouritaki, S. B., Theodoropoulos, P. A., Gravanis, A., \& Stournaras, C. (1994). Differences in the $\mathrm{G} /$ total actin ratio and microfilament stability between normal and malignant human keratinocytes. Cell Biochem Funct, 12(4), 267-274. doi:10.1002/cbf.290120407

Ketene, A. N., Schmelz, E. M., Roberts, P. C., \& Agah, M. (2012). The effects of cancer progression on the viscoelasticity of ovarian cell cytoskeleton structures. Nanomedicine, 8(1), 93-102. doi:10.1016/j.nano.2011.05.012

Kießling, T. R., Stange, R., Kas, J. A., \& Fritsch, A. W. (2013). Thermorheology of living cells-impact of temperature variations on cell mechanics. New Journal of Physics, 15. doi:10.1088/13672630/15/4/045026

Koch, T. M., Münster, S. , Bonakdar, N. , Butler, J.P. , Fabry, B. (2012). 3D Traction Forces in Cancer Cell Invasion. PLOS ONE, 7. doi:10.1371/journal.pone.0033476

Kollmannsberger, P., \& Fabry, B. (2009). Active soft glassy rheology of adherent cells. In (Vol. 5, pp. 1771-1774). Soft Matter.

Kraning-Rush, C. M., Califano, J. P., \& Reinhart-King, C. A. (2012). Cellular traction stresses increase with increasing metastatic potential. PLoS One, 7(2), e32572. doi:10.1371/journal.pone.0032572

Kumar, S., \& Weaver, V. M. (2009). Mechanics, malignancy, and metastasis: the force journey of a tumor cell. Cancer Metastasis Rev, 28(1-2), 113-127. doi:10.1007/s10555-008-9173-4

Lancaster, O. M., Le Berre, M., Dimitracopoulos, A., Bonazzi, D., Zlotek-Zlotkiewicz, E., Picone, R., ... . Baum, B. (2013). Mitotic rounding alters cell geometry to ensure efficient bipolar spindle formation. Dev Cell, 25(3), 270-283. doi:10.1016/j.devcel.2013.03.014

Lange, J. R., \& Fabry, B. (2013). Cell and tissue mechanics in cell migration. Exp Cell Res, 319(16), 2418-2423. doi:10.1016/j.yexcr.2013.04.023

Lange, J. R., Steinwachs, J., Kolb, T., Lautscham, L. A., Harder, I., Whyte, G., \& Fabry, B. (2015). Microconstriction arrays for high-throughput quantitative measurements of cell mechanical properties. Biophys J, 109(1), 26-34. doi:10.1016/j.bpj.2015.05.029 
Lautscham, L. A., Kämmerer, C., Lange, J. R., Kolb, T., Mark, C., Schilling, A., . . Fabry, B. (2015). Migration in Confined 3D Environments Is Determined by a Combination of Adhesiveness, Nuclear Volume, Contractility, and Cell Stiffness. Biophys J, 109(5), 900-913. doi:10.1016/j.bpj.2015.07.025

Le Bras, G. F., Taubenslag, K. J., \& Andl, C. D. (2012). The regulation of cell-cell adhesion during epithelial-mesenchymal transition, motility and tumor progression. Cell Adh Migr, 6(4), 365373. doi:10.4161/cam.21326

Lee, L. M., \& Liu, A. P. (2014). The Application of Micropipette Aspiration in Molecular Mechanics of Single Cells. J Nanotechnol Eng Med, 5(4), 0408011-0408016. doi:10.1115/1.4029936

Lekka, M., Laidler, P., Gil, D., Lekki, J., Stachura, Z., \& Hrynkiewicz, A. Z. (1999). Elasticity of normal and cancerous human bladder cells studied by scanning force microscopy. Eur Biophys $J$, 28(4), 312-316.

Lekka, M., Pogoda, K., Gostek, J., Klymenko, O., Prauzner-Bechcicki, S., Wiltowska-Zuber, J., . . . Stachura, Z. (2012). Cancer cell recognition--mechanical phenotype. Micron, 43(12), 12591266. doi:10.1016/j.micron.2012.01.019

Leve, F., \& Morgado-Díaz, J. A. (2012). Rho GTPase signaling in the development of colorectal cancer. J Cell Biochem, 113(8), 2549-2559. doi:10.1002/jcb.24153

Levental, K. R., Yu, H., Kass, L., Lakins, J. N., Egeblad, M., Erler, J. T., .. W Weaver, V. M. (2009). Matrix crosslinking forces tumor progression by enhancing integrin signaling. Cell, 139(5), 891-906. doi:10.1016/j.cell.2009.10.027

Li, S., Chen, M., Wang, W., Zhao, W., Wang, J., Zhao, X., \& Zhou, C. (2011). A feasibility study of MR elastography in the diagnosis of prostate cancer at 3.0T. Acta Radiol, 52(3), 354-358. doi:10.1258/ar.2010.100276

Li, Y., Schnekenburger, J., \& Duits, M. H. (2009). Intracellular particle tracking as a tool for tumor cell characterization. J Biomed Opt, 14(6), 064005. doi:10.1117/1.3257253

Lim, C. T., Zhou, E. H., \& Quek, S. T. (2006). Mechanical models for living cells--a review. J Biomech, 39(2), 195-216. doi:10.1016/j.jbiomech.2004.12.008

Lintz, M., Muñoz, A., \& Reinhart-King, C. A. (2016). The Mechanics of Single Cell and Collective Migration of Tumor Cells. J Biomech Eng. doi:10.1115/1.4035121

Liu, C. Y., Lin, H. H., Tang, M. J., \& Wang, Y. K. (2015). Vimentin contributes to epithelialmesenchymal transition cancer cell mechanics by mediating cytoskeletal organization and focal adhesion maturation. Oncotarget, 6(18), 15966-15983. doi:10.18632/oncotarget.3862

Liu, Y., Cheng, D. K., Sonek, G. J., Berns, M. W., Chapman, C. F., \& Tromberg, B. J. (1995). Evidence for localized cell heating induced by infrared optical tweezers. Biophys J, 68(5), 2137-2144. doi:10.1016/S0006-3495(95)80396-6

Lorenzen, J., Sinkus, R., Lorenzen, M., Dargatz, M., Leussler, C., Röschmann, P., \& Adam, G. (2002). MR elastography of the breast:preliminary clinical results. Rofo, 174(7), 830-834. doi:10.1055/s-2002-32690

Lu, P., Weaver, V. M., \& Werb, Z. (2012). The extracellular matrix: a dynamic niche in cancer progression. J Cell Biol, 196(4), 395-406. doi:10.1083/jcb.201102147

Mackay, J. L., \& Kumar, S. (2013). Measuring the elastic properties of living cells with atomic force microscopy indentation. Methods Mol Biol, 931, 313-329. doi:10.1007/978-1-62703-0564_15

Mak, M., Kamm, R. D., \& Zaman, M. H. (2014). Impact of dimensionality and network disruption on microrheology of cancer cells in 3D environments. PLoS Comput Biol, 10(11), e1003959. doi:10.1371/journal.pcbi.1003959

Mandadapu, K. K., Govindjee, S., \& Mofrad, M. R. (2008). On the cytoskeleton and soft glassy rheology. J Biomech, 41(7), 1467-1478. doi:10.1016/j.jbiomech.2008.02.014

Mandal, K., Asnacios, A., Goud, B., \& Manneville, J. B. (2016). Mapping intracellular mechanics on micropatterned substrates. Proc Natl Acad Sci U S A. doi:10.1073/pnas.1605112113 
Manneville, J.-B., Bassereau, P., Lévy, D., Prost, J. (1999). Activity of Transmembrane Proteins Induces Magnification of Shape Fluctuations of Lipid Membranes. Physical Review Letters, 82, 4356-4359. doi:10.1103/PhysRevLett.82.4356

McGregor, A. L., Hsia, C. R., \& Lammerding, J. (2016). Squish and squeeze-the nucleus as a physical barrier during migration in confined environments. Curr Opin Cell Biol, 40, 32-40. doi:10.1016/j.ceb.2016.01.011

Meacham, C. E., \& Morrison, S. J. (2013). Tumour heterogeneity and cancer cell plasticity. Nature, 501(7467), 328-337. doi:10.1038/nature12624

Mierke, C. T. (2013). Physical break-down of the classical view on cancer cell invasion and metastasis. Eur J Cell Biol, 92(3), 89-104. doi:10.1016/j.ejcb.2012.12.002

Mierke, C. T. (2014). The fundamental role of mechanical properties in the progression of cancer disease and inflammation. Rep Prog Phys, 77(7), 076602. doi:10.1088/00344885/77/7/076602

Mierke, C. T., Rösel, D., Fabry, B., \& Brábek, J. (2008). Contractile forces in tumor cell migration. Eur J Cell Biol, 87(8-9), 669-676. doi:10.1016/j.ejcb.2008.01.002

Mittelman, L., Levin, S., Verschueren, H., Debaetselier, P., \& Korenstein, R. (1994). Direct correlation between cell membrane fluctuations, cell filterability and the metastatic potential of lymphoid cell lines. Biochemical and Biophysical Research Communications, 203. doi:10.1006/bbrc.1994.2267

Moeendarbary, E., Valon, L., Fritzsche, M., Harris, A. R., Moulding, D. A., Thrasher, A. J., . . Charras, G. T. (2013). The cytoplasm of living cells behaves as a poroelastic material. Nat Mater, 12(3), 253-261. doi:10.1038/nmat3517

N. Desprat, A. G., and A. Asnacios. (2006). Microplates-based rheometer for a single living cell. Review of Scientific Instruments, 77(055111). doi:10.1063/1.2202921

Ngan, C. Y., Yamamoto, H., Seshimo, I., Tsujino, T., Man-i, M., Ikeda, J. I., . . Monden, M. (2007). Quantitative evaluation of vimentin expression in tumour stroma of colorectal cancer. $\mathrm{Br} \mathrm{J}$ Cancer, 96(6), 986-992. doi:10.1038/sj.bjc.6603651

Nijenhuis, N., Zhao, X., Carisey, A., Ballestrem, C., \& Derby, B. (2014). Combining AFM and acoustic probes to reveal changes in the elastic stiffness tensor of living cells. Biophys J, 107(7), 15021512. doi:10.1016/j.bpj.2014.07.073

Nowak, D., Krawczenko, A., Duś, D., \& Malicka-Błaszkiewicz, M. (2002). Actin in human colon adenocarcinoma cells with different metastatic potential. Acta Biochim Pol, 49(4), 823-828. doi:024904823

Nürnberg, A., Kitzing, T., \& Grosse, R. (2011). Nucleating actin for invasion. Nat Rev Cancer, 11(3), 177-187. doi:10.1038/nrc3003

Ohashi, T., Hagiwara, M., Bader, D. L., \& Knight, M. M. (2006). Intracellular mechanics and mechanotransduction associated with chondrocyte deformation during pipette aspiration. Biorheology, 43(3-4), 201-214.

Okajima, T. (2012). Atomic force microscopy for the examination of single cell rheology. Curr Pharm Biotechnol, 13(14), 2623-2631.

Omidvar, R., Tafazzoli-Shadpour, M., Shokrgozar, M. A., \& Rostami, M. (2014). Atomic force microscope-based single cell force spectroscopy of breast cancer cell lines: an approach for evaluating cellular invasion. J Biomech, 47(13), 3373-3379. doi:10.1016/j.jbiomech.2014.08.002

Orgaz, J. L., Herraiz, C., \& Sanz-Moreno, V. (2014). Rho GTPases modulate malignant transformation of tumor cells. Small GTPases, 5, e29019. doi:10.4161/sgtp.29019

Otto, O., Rosendahl, P., Mietke, A., Golfier, S., Herold, C., Klaue, D., . . Guck, J. (2015). Real-time deformability cytometry: on-the-fly cell mechanical phenotyping. Nat Methods, 12(3), 199202, 194 p following 202. doi:10.1038/nmeth.3281 
Pachenari, M., Seyedpour, S. M., Janmaleki, M., Babazadeh Shayan, S., Taranejoo, S., \& Hosseinkhani, H. (2014). Mechanical properties of cancer cytoskeleton depend on actin filaments to microtubules content: investigating different grades of colon cancer cell lines. J Biomech, 47(2), 373-379. doi:10.1016/j.jbiomech.2013.11.020

Park, J. A., Atia, L., Mitchel, J. A., Fredberg, J. J., \& Butler, J. P. (2016). Collective migration and cell jamming in asthma, cancer and development. J Cell Sci, 129(18), 3375-3383. doi:10.1242/jcs.187922

Park, S., Koch, D., Cardenas, R., Käs, J., \& Shih, C. K. (2005). Cell motility and local viscoelasticity of fibroblasts. Biophys J, 89(6), 4330-4342. doi:10.1529/biophysj.104.053462

Partin, A. W., Schoeniger, J. S., Mohler, J. L., \& S., C. D. (1989). Fourier analysis of cell motility: Correlation of motility with metastatic potential In (Vol. 86, pp. 1254-1258). Proceedings of the National Academy of Sciences.

Paszek, M. J., Zahir, N., Johnson, K. R., Lakins, J. N., Rozenberg, G. I., Gefen, A., ... Weaver, V. M. (2005). Tensional homeostasis and the malignant phenotype. Cancer Cell, 8(3), 241-254. doi:10.1016/j.ccr.2005.08.010

Pawlizak, S., Fritsch, A. W., Grosser, S., Ahrens, D., Thalheim, T., Riedel, S., . . Käs, J. A. (2015). Testing the differential adhesion hypothesis across the epithelial - mesenchymal transition. New Journal of Physics, 17. doi:10.1088/1367-2630/17/8/083049

Peckham, M. (2016). How myosin organization of the actin cytoskeleton contributes to the cancer phenotype. Biochem Soc Trans, 44(4), 1026-1034. doi:10.1042/BST20160034

Pepin, K. M., Ehman, R. L., \& McGee, K. P. (2015). Magnetic resonance elastography (MRE) in cancer: Technique, analysis, and applications. Prog Nucl Magn Reson Spectrosc, 90-91, 32-48. doi:10.1016/j.pnmrs.2015.06.001

Peschetola, V., Laurent, V. M., Duperray, A., Michel, R., Ambrosi, D., Preziosi, L., \& Verdier, C. (2013). Time-dependent traction force microscopy for cancer cells as a measure of invasiveness. Cytoskeleton (Hoboken), 70(4), 201-214. doi:10.1002/cm.21100

Pickup, M. W., Mouw, J.K., Weaver , V. M. (2014). The extracellular matrix modulates the hallmarks of cancer. EMBO reports, 15. doi:10 . 15252 /embr. 201439246

Plodinec, M., Loparic, M., Monnier, C. A., Obermann, E. C., Zanetti-Dallenbach, R., Oertle, P., . . . Schoenenberger, C. A. (2012). The nanomechanical signature of breast cancer. Nat Nanotechnol, 7(11), 757-765. doi:10.1038/nnano.2012.167

Prabhune, M., Belge, G., Dotzauer, A., Bullerdiek, J., \& Radmacher, M. (2012). Comparison of mechanical properties of normal and malignant thyroid cells. Micron, 43(12), 1267-1272. doi:10.1016/j.micron.2012.03.023

Prager-Khoutorsky, M., Lichtenstein, A., Krishnan, R., Rajendran, K., Mayo, A., Kam, Z., . . Bershadsky, A. D. (2011). Fibroblast polarization is a matrix-rigidity-dependent process controlled by focal adhesion mechanosensing. Nat Cell Biol, 13(12), 1457-1465. doi:10.1038/ncb2370

Prass, M., Jacobson, K., Mogilner, A., \& Radmacher, M. (2006). Direct measurement of the lamellipodial protrusive force in a migrating cell. J Cell Biol, 174(6), 767-772. doi:10.1083/jcb.200601159

Raab, M., Gentili, M., de Belly, H., Thiam, H. R., Vargas, P., Jimenez, A. J., . . Piel, M. (2016). ESCRT III repairs nuclear envelope ruptures during cell migration to limit DNA damage and cell death. Science, 352(6283), 359-362. doi:10.1126/science.aad7611

Rebelo, L. M., de Sousa, J. S., Mendes Filho, J., \& Radmacher, M. (2013). Comparison of the viscoelastic properties of cells from different kidney cancer phenotypes measured with atomic force microscopy. Nanotechnology, 24(5), 055102. doi:10.1088/09574484/24/5/055102

Reiss-Zimmermann, M., Streitberger, K. J., Sack, I., Braun, J., Arlt, F., Fritzsch, D., \& Hoffmann, K. T. (2015). High Resolution Imaging of Viscoelastic Properties of Intracranial Tumours by Multi- 
Frequency Magnetic Resonance Elastography. Clin Neuroradiol, 25(4), 371-378. doi:10.1007/s00062-014-0311-9

Remmerbach, T. W., Wottawah, F., Dietrich, J., Lincoln, B., Wittekind, C., \& Guck, J. (2009). Oral cancer diagnosis by mechanical phenotyping. Cancer Res, 69(5), 1728-1732. doi:10.1158/0008-5472.CAN-08-4073

Rieu, J. P., Barentin, C., Maeda, Y., \& Sawada, Y. (2005). Direct mechanical force measurements during the migration of Dictyostelium slugs using flexible substrata. Biophys J, 89(5), 35633576. doi:10.1529/biophysj.104.056333

Rigato, A., Rico, F., Eghiaian, F., Piel, M., \& Scheuring, S. (2015). Atomic Force Microscopy Mechanical Mapping of Micropatterned Cells Shows Adhesion Geometry-Dependent Mechanical Response on Local and Global Scales. ACS Nano, 9(6), 5846-5856. doi:10.1021/acsnano.5b00430

Rother, J., Nöding, H., Mey, I., \& Janshoff, A. (2014). Atomic force microscopy-based microrheology reveals significant differences in the viscoelastic response between malign and benign cell lines. Open Biol, 4(5), 140046. doi:10.1098/rsob.140046

Rönnlund, D., Gad, A. K., Blom, H., Aspenström, P., \& Widengren, J. (2013). Spatial organization of proteins in metastasizing cells. Cytometry A, 83(9), 855-865. doi:10.1002/cyto.a.22304

Salbreux, G., Charras, G., \& Paluch, E. (2012). Actin cortex mechanics and cellular morphogenesis. Trends Cell Biol, 22(10), 536-545. doi:10.1016/j.tcb.2012.07.001

Savagner, P. (2010). The epithelial-mesenchymal transition (EMT) phenomenon. Ann Oncol, 21 Suppl 7, vii89-92. doi:10.1093/annonc/mdq292

Schmidt, B. U. S., Kießling , T. R., Warmt , E., Fritsch , A. W., Stange , R., \& Käs , J. A. (2015). Complex thermorheology of living cells. New Journal of physics, 17. doi:10.1088/13672630/17/7/073010

Seltmann, K., Fritsch, A. W., Käs, J. A., \& Magin, T. M. (2013). Keratins significantly contribute to cell stiffness and impact invasive behavior. Proc Natl Acad Sci U S A, 110(46), 18507-18512. doi:10.1073/pnas.1310493110

Stamenović, D., Rosenblatt, N., Montoya-Zavala, M., Matthews, B. D., Hu, S., Suki, B., . . Ingber, D. E. (2007). Rheological behavior of living cells is timescale-dependent. Biophys J, 93(8), L39-41. doi:10.1529/biophysj.107.116582

Suresh, S. (2007). Biomechanics and biophysics of cancer cells. Acta Biomater, 3(4), 413-438. doi:10.1016/j.actbio.2007.04.002

Suresh, S., Spatz, J., Mills, J. P., Micoulet, A., Dao, M., Lim, C. T., . . Seufferlein, T. (2005). Connections between single-cell biomechanics and human disease states: gastrointestinal cancer and malaria. Acta Biomater, 1(1), 15-30. doi:10.1016/j.actbio.2004.09.001

Swaminathan, V., Mythreye, K., O'Brien, E. T., Berchuck, A., Blobe, G. C., \& Superfine, R. (2011). Mechanical stiffness grades metastatic potential in patient tumor cells and in cancer cell lines. Cancer Res, 71(15), 5075-5080. doi:10.1158/0008-5472.CAN-11-0247

Tanter, M., Bercoff, J., Athanasiou, A., Deffieux, T., Gennisson, J. L., Montaldo, G., . . Fink, M. (2008). Quantitative assessment of breast lesion viscoelasticity: initial clinical results using supersonic shear imaging. Ultrasound Med Biol, 34(9), 1373-1386. doi:10.1016/j.ultrasmedbio.2008.02.002

Tee, S. Y., Fu, J., Chen, C. S., \& Janmey, P. A. (2011). Cell shape and substrate rigidity both regulate cell stiffness. Biophys J, 100(5), L25-27. doi:10.1016/j.bpj.2010.12.3744

Thomas, P. A., Kirschmann, D. A., Cerhan, J. R., Folberg, R., Seftor, E. A., Sellers, T. A., \& Hendrix, M. J. (1999). Association between keratin and vimentin expression, malignant phenotype, and survival in postmenopausal breast cancer patients. Clin Cancer Res, 5(10), 2698-2703.

Thoumine, O., \& Ott, A. (1997a). Comparison of the mechanical properties of normal and transformed fibroblasts. Biorheology, 34(4-5), 309-326. doi:10.1016/S0006-355X(98)00007-9 
Thoumine, O., \& Ott, A. (1997b). Time scale dependent viscoelastic and contractile regimes in fibroblasts probed by microplate manipulation. J Cell Sci, 110 ( Pt 17), 2109-2116.

Torsvik, A., Stieber, D., Enger, P., Golebiewska, A., Molven, A., Svendsen, A., . . Bjerkvig, R. (2014). U-251 revisited: genetic drift and phenotypic consequences of long-term cultures of glioblastoma cells. Cancer Med, 3(4), 812-824. doi:10.1002/cam4.219

Tseng, Y., Kole, T. P., \& Wirtz, D. (2002). Micromechanical mapping of live cells by multiple-particletracking microrheology. Biophys J, 83(6), 3162-3176. doi:10.1016/S0006-3495(02)75319-8

Tuvia, S., Levin, S., Bitler, A., \& Korenstein, R. (1998). Mechanical fluctuations of the membraneskeleton are dependent on F-actin ATPase in human erythrocytes. J Cell Biol, 141(7), 15511561.

Tzeng, H. T., \& Wang, Y. C. (2016). Rab-mediated vesicle trafficking in cancer. J Biomed Sci, 23(1), 70. doi:10.1186/s12929-016-0287-7

Valastyan, S., \& Weinberg, R. A. (2011). Tumor metastasis: molecular insights and evolving paradigms. Cell, 147(2), 275-292. doi:10.1016/j.cell.2011.09.024

Venkatesh, S. K., Yin, M., Glockner, J. F., Takahashi, N., Araoz, P. A., Talwalkar, J. A., \& Ehman, R. L. (2008). MR elastography of liver tumors: preliminary results. AJR Am J Roentgenol, 190(6), 1534-1540. doi:10.2214/AJR.07.3123

Vignjevic, D., \& Montagnac, G. (2008). Reorganisation of the dendritic actin network during cancer cell migration and invasion. Semin Cancer Biol, 18(1), 12-22. doi:10.1016/j.semcancer.2007.08.001

Wang, B., Lançon, P., Bienvenu, C., Vierling, P., Di Giorgio, C., \& Bossis, G. (2013). A general approach for the microrheology of cancer cells by atomic force microscopy. Micron, 44, 287-297. doi:10.1016/j.micron.2012.07.006

Wang, N., Naruse, K., Stamenović, D., Fredberg, J. J., Mijailovich, S. M., Tolić-Nørrelykke, I. M., ... Ingber, D. E. (2001). Mechanical behavior in living cells consistent with the tensegrity model. Proc Natl Acad Sci U S A, 98(14), 7765-7770. doi:10.1073/pnas.141199598

Wang, X., Peralta, S., \& Moraes, C. T. (2013). Mitochondrial alterations during carcinogenesis: a review of metabolic transformation and targets for anticancer treatments. Adv Cancer Res, 119, 127-160. doi:10.1016/B978-0-12-407190-2.00004-6

Weaver, W. M., Tseng, P., Kunze, A., Masaeli, M., Chung, A. J., Dudani, J. S., . . Di Carlo, D. (2014). Advances in high-throughput single-cell microtechnologies. Curr Opin Biotechnol, 25, 114123. doi:10.1016/j.copbio.2013.09.005

Wilhelm, C., Gazeau, F., \& Bacri, J. C. (2003). Rotational magnetic endosome microrheology: viscoelastic architecture inside living cells. Phys Rev E Stat Nonlin Soft Matter Phys, 67(6 Pt 1), 061908. doi:10.1103/PhysRevE.67.061908

Willipinski-Stapelfeldt, B., Riethdorf, S., Assmann, V., Woelfle, U., Rau, T., Sauter, G., . . Pantel, K. (2005). Changes in cytoskeletal protein composition indicative of an epithelial-mesenchymal transition in human micrometastatic and primary breast carcinoma cells. Clin Cancer Res, 11(22), 8006-8014. doi:10.1158/1078-0432.CCR-05-0632

Wirtz, D. (2009). Particle-tracking microrheology of living cells: principles and applications. Annu Rev Biophys, 38, 301-326. doi:10.1146/annurev.biophys.050708.133724

World Health Organization Classification of Tumours. (2004). In Pathology and Genetics of Tumours of the Urinary System and Male Genital Organs: IARCPress.

Wottawah, F., Schinkinger, S., Lincoln, B., Ananthakrishnan, R., Romeyke, M., Guck, J., \& Käs, J. (2005). Optical rheology of biological cells. Phys Rev Lett, 94(9), 098103. doi:10.1103/PhysRevLett.94.098103

Wu, P. H., Hale, C. M., Chen, W. C., Lee, J. S., Tseng, Y., \& Wirtz, D. (2012). High-throughput ballistic injection nanorheology to measure cell mechanics. Nat Protoc, 7(1), 155-170.

doi:10.1038/nprot.2011.436 
Xie, Y., Bergström, T., Jiang, Y., Johansson, P., Marinescu, V. D., Lindberg, N., . . Uhrbom, L. (2015). The Human Glioblastoma Cell Culture Resource: Validated Cell Models Representing All Molecular Subtypes. EBioMedicine, 2(10), 1351-1363. doi:10.1016/j.ebiom.2015.08.026

Xu, W., Mezencev, R., Kim, B., Wang, L., McDonald, J., \& Sulchek, T. (2012). Cell stiffness is a biomarker of the metastatic potential of ovarian cancer cells. PLoS One, 7(10), e46609. doi:10.1371/journal.pone.0046609

Yamada, S., Wirtz, D., \& Kuo, S. C. (2000). Mechanics of living cells measured by laser tracking microrheology. Biophys J, 78(4), 1736-1747. doi:10.1016/S0006-3495(00)76725-7

Yao, A., Tassieri, M., Padgett, M., \& Cooper, J. (2009). Microrheology with optical tweezers. Lab Chip, 9(17), 2568-2575. doi:10.1039/b907992k

Ye, Z., Zhang, X., Luo, Y., Li, S., Huang, L., Li, Z., . . Chen, G. (2016). Prognostic Values of Vimentin Expression and Its Clinicopathological Significance in Non-Small Cell Lung Cancer: A MetaAnalysis of Observational Studies with 4118 Cases. PLoS One, 11(9), e0163162. doi:10.1371/journal.pone.0163162

Zemel, A., Rehfeldt, F., Brown, A. E., Discher, D. E., \& Safran, S. A. (2010). Optimal matrix rigidity for stress fiber polarization in stem cells. Nat Phys, 6(6), 468-473. doi:10.1038/nphys1613

Zhang, G., Long, M., Wu, Z. Z., \& Yu, W. Q. (2002). Mechanical properties of hepatocellular carcinoma cells. World J Gastroenterol, 8(2), 243-246.

Zhang, W., Kai, K., Ueno, N. T., \& Qin, L. (2013). A Brief Review of the Biophysical Hallmarks of Metastatic Cancer Cells. Cancer Hallm, 1(2-3), 59-66. doi:10.1166/ch.2013.1010

Zwerger, M., Ho, C. Y., \& Lammerding, J. (2011). Nuclear mechanics in disease. Annu Rev Biomed Eng, 13, 397-428. doi:10.1146/annurev-bioeng-071910-124736

\section{Figure and table legends}

\section{Figure 1}

Experimental techniques used to compare the rheological properties of healthy and cancer cells at the scale of the whole cell (left) or at the local scale (right). Micropipette aspiration (a) or optical stretcher (b) probe mechanics by imposing a stretch deformation of the whole cell, while microfluidic devices (c) force cells to flow or migrate through channels of imposed geometries. Local indentation of the cells can be performed using an atomic force microscope (AFM) cantilever to which a bead or another cell is attached (d). Intracellular passive microrheology measures the local mechanics of the cell interior by tracking the movement of an internalized probe (e). In active microrheology, a force is applied on the probe using magnetic or optical tweezers ( $f$ ). 


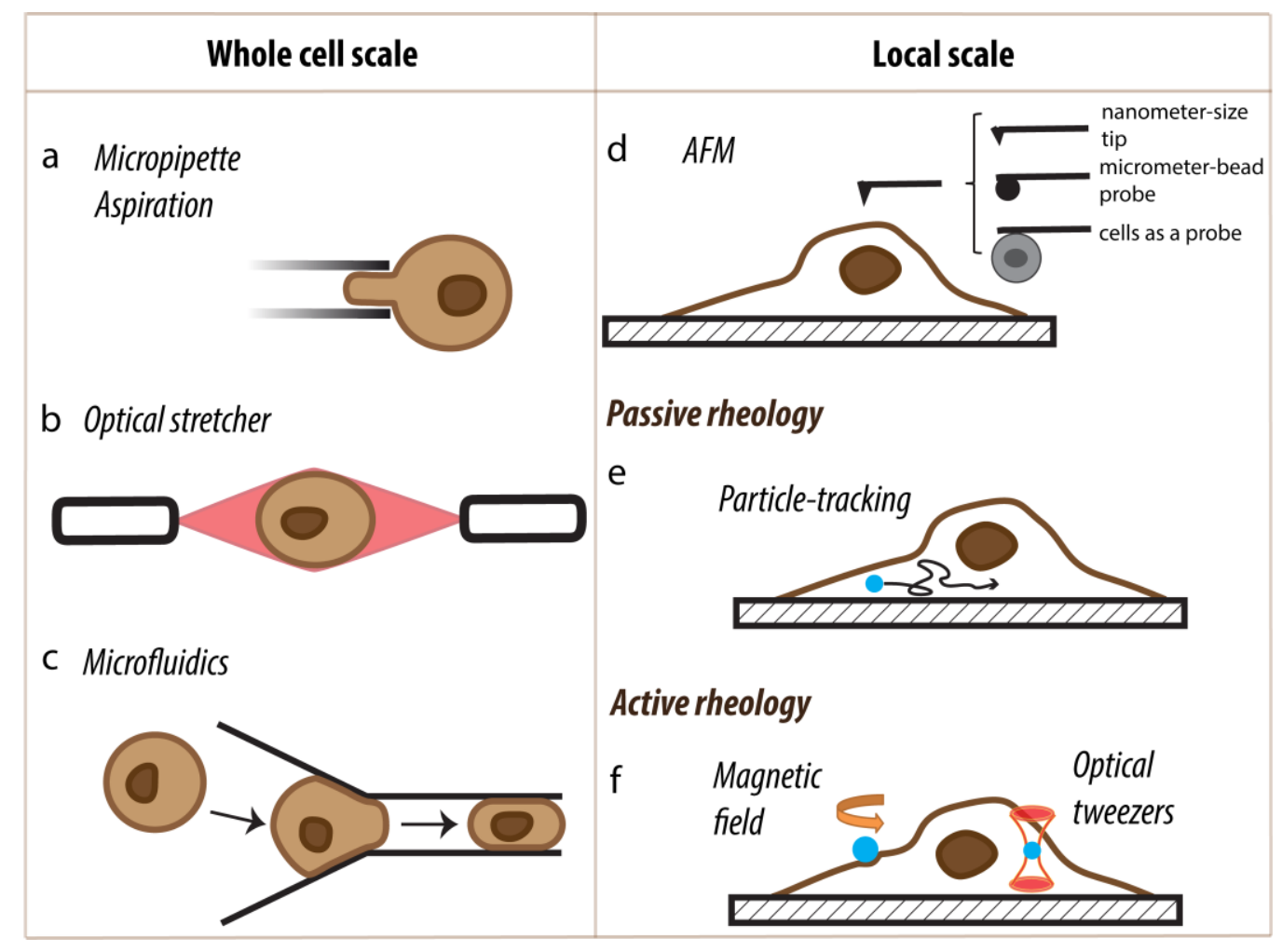

Figure 2

Basic rheology: concepts, models, mechanical parameters and their time-dependent or frequencydependent behavior in a creep experiment. (A) Definition of the stress $\sigma(\mathrm{Pa})$ and the strain $\varepsilon$ (dimensionless) in a material submitted to a shear stress. The bottom plane of the material is fixed while a force $\mathrm{F}$ is applied to the top plane in a direction parallel to the surface $\mathrm{S}$. (B) Creep and stressrelaxation experiments. In a creep (resp. stress relaxation) experiment a constant stress (resp. strain) is applied. From the evolution of the strain (resp. stress) with time, the creep compliance $\mathrm{J}(\mathrm{t}$ ) of the material can be deduced. $J(t)$ is the inverse of the shear modulus $G(t)$. (C) Simple models in rheology. a- An elastic Hookean solid is symbolized by a spring of spring constant $\mathrm{K}(\mathrm{N} / \mathrm{m})$ and Young modulus $\mathrm{E}(\mathrm{Pa})$. The stress is proportional to the strain and the proportionality constant is the Young modulus $\mathrm{E}(\mathrm{Pa})$. b- A Newtonian fluid of viscosity $\eta$ (Pa.s) is symbolized by a single dashpot. The stress is proportional to the time derivative of the strain and the proportionality constant is the viscosity $\eta$ (Pa.s). c- Maxwell model of a visco-elastic material. The material behaves as an elastic solid at short time scales $(t \ll \tau$, where $\tau$ is the time constant $\tau=\eta / E)$ and as a viscous fluid at long time scales $(t \gg \tau)$. $d$ - Kelvin-Voigt model of a visco-elastic material. The material behaves as a viscous fluid at short time scales $(t \ll \tau)$ and as an elastic solid at long time scales $(t \gg \tau)$. (D) More complex models used to describe cellular rheology. a- The Standard Linear Solid (SLS) model is composed of a Kelvin-Voigt element in series with a spring. b- The Standard Linear Liquid (SLL) model is composed of a Kelvin-Voigt element in series with a dashpot. c- Models with a continuous distribution of time scales are represented by an infinite number of Kelvin-Voigt or Maxwell elementary elements and lead to a power-law behavior. 
A

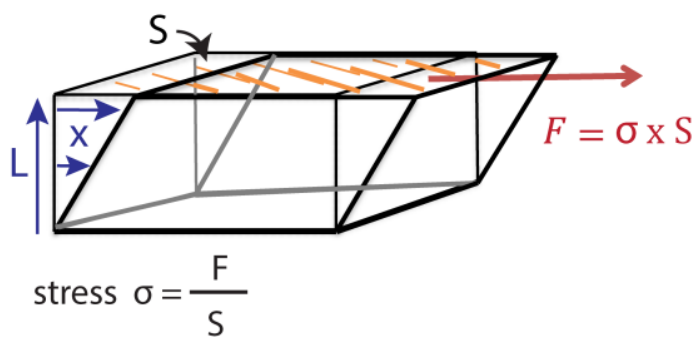

strain $\varepsilon=\frac{\mathrm{X}}{\mathrm{L}}$

shear modulus $\left\{\begin{array}{l}G(t)=\frac{\sigma(t)}{\varepsilon(t)} \\ G(\omega)=G^{\prime}(\omega)+i G^{\prime \prime}(\omega)\end{array}\right.$

creep compliance $J(t)=\frac{1}{G(t)}$

C

a- Hookean elastic solid

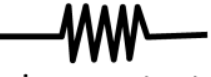

Spring constant $\mathrm{K}$

Young's modulus $E$

$\sigma=\mathrm{E} \varepsilon$

$\mathrm{G}^{\prime \prime}(\omega)=0$

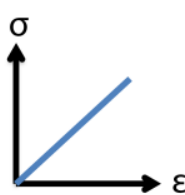

B Creep experiment

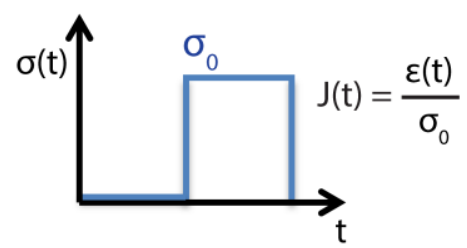

Stress-relaxation experiment

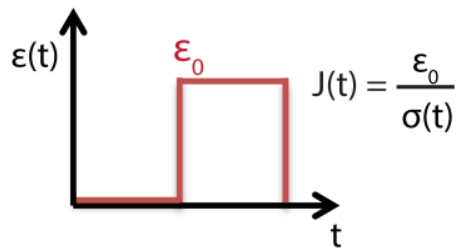

b- Newtonian viscous fluid
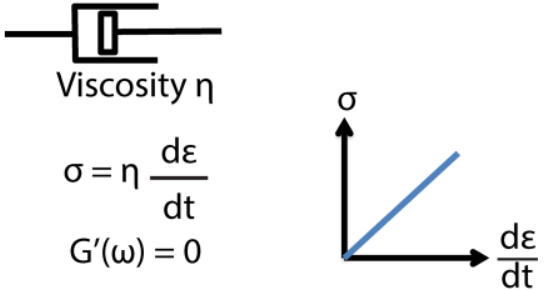

c- Maxwell model

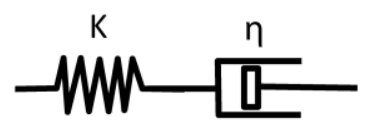

d- Kelvin-Voigt model

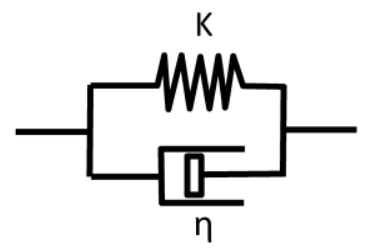

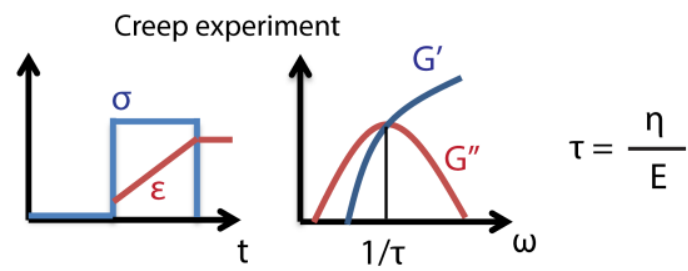

Creep experiment
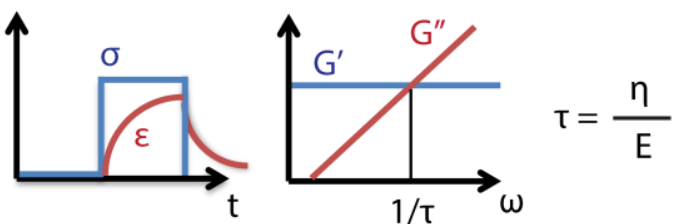

a- Standard linear solid (SLS) model

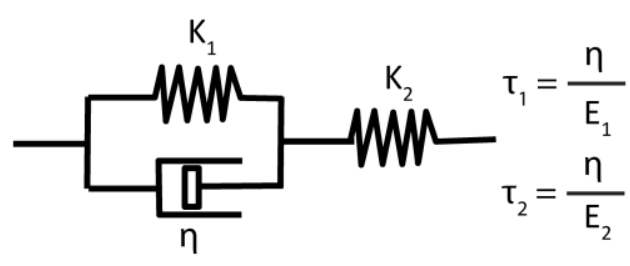

b- Standard linear liquid (SLL) model

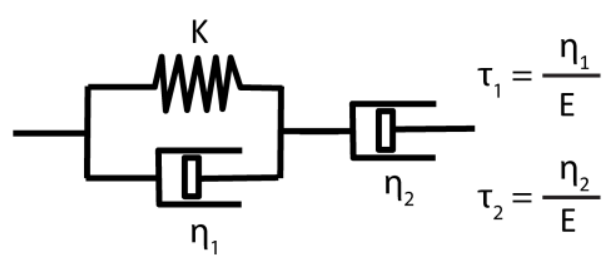

c- Continuous distribution of time constants

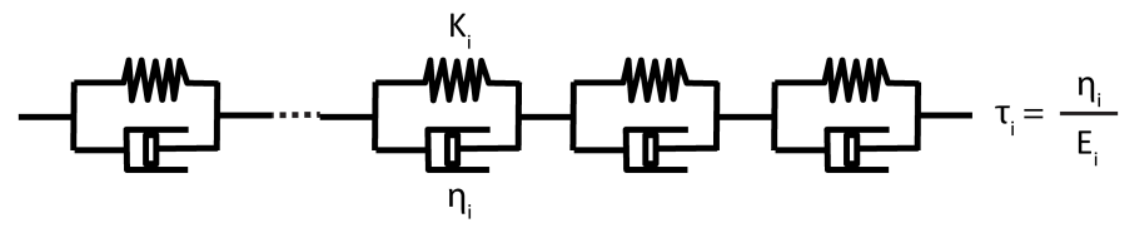




\section{Figure 3}

Cellular constituents that contribute or could contribute to the differences in rheological behaviors observed between healthy cells and cancer cells. Elements labelled with a star $\left({ }^{*}\right)$ change their characteristics during cell transformation. Elements listed on the left (ECM, actin, intermediate filaments) have been shown to directly impact on cell stiffness. In contrast, elements listed on the right (myosin II, E-cadherin, microtubules, energy sources such as ATP or GTP, internal membranes and trafficking) are known to contribute to cell stiffness but the mechanism and whether the contribution is direct or indirect is not clear yet. The cartoon compares the organization of a normal cell (left) with that of a cancer cell (right). In cancer cells, the nucleus volume is larger and the nuclear envelope is abnormally deformed and perforated; stress fibers are less dense and less organized; extra centrosomes appear with an elongated shape and abnormal positioning; and Ecadherin expression is reduced. Several studies have established that modifications of the actin cytoskeleton contribute to the mechanical differences between normal and cancer cells. Similarly, changes in the extracellular matrix (ECM) stiffness and of the expression levels of intermediate filament proteins, could explain changes in cell mechanics observed in cancer. Cancer cells are also known to sustain higher levels of ATP produced by glycolysis rather than by mitochondria as in normal cells. Intracellular out-of-equilibrium (active) forces which depend on the energy produced by ATP or GTP hydrolysis, such as the forces exerted by molecular motors, could thus be increased in cancer cells. Other cellular constituents altered in cancer, such as internal membrane organelles and their associated signaling molecules, myosin II or the microtubule network, have been proposed to impact on cell rigidity but their exact contribution is still debated.
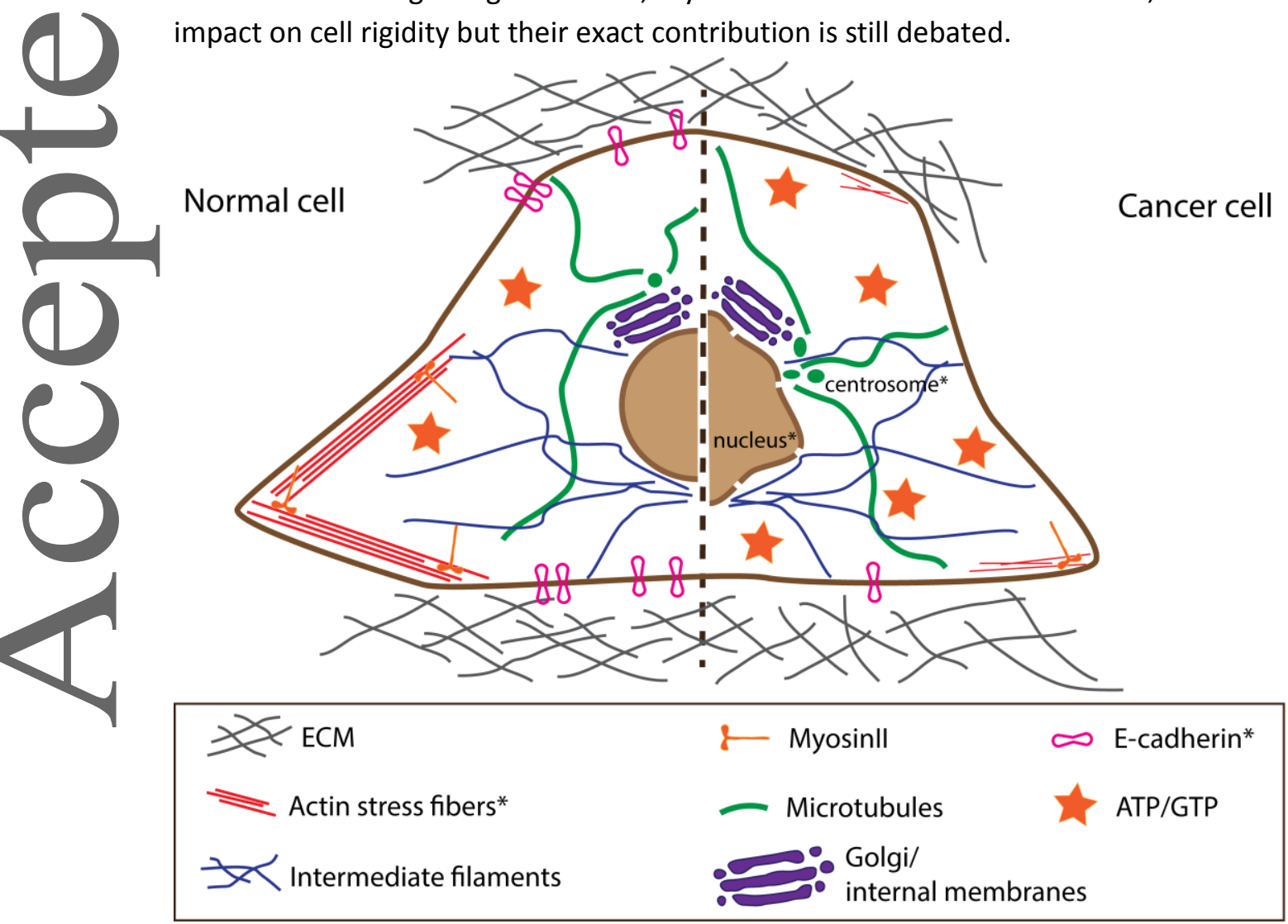


\section{Table 1}

Summary of the studies showing that individual cancer cells are softer than normal cells and/or that softness correlates with malignancy. References are sorted according to the main experimental technique used in the paper. For each reference, we report the cancer type and cell lines, the measured rheological parameters, the theoretical model and, when applicable, the cytoskeletal element specifically targeted in the study. $\mathrm{E}(\mathrm{Pa})$ represents the Young modulus or the elastic constant depending on the analysis, $\mathrm{K}(\mathrm{N} / \mathrm{m})$ represents the elastic spring constant when a model using springs is used to describe cells or cellular environment, and $\mu$ (Pa.s) corresponds to the viscosity. J, G, G', G' and $\mathrm{G}_{0}$ are respectively the compliance (in $\mathrm{Pa}^{-1}$ ), the complex shear modulus (in $\mathrm{Pa})$, its real and imaginary parts and its modulus. A star on the reference indicates Atomic Force Microscopy (AFM) experiments done with micron-sized beads as the probe. Colors represent the progression of the disease in the same organ or at the same localization inside the body (green = normal cells or low metastatic potential, orange $=$ intermediate metastatic potential, red $=$ highest metastatic potential). Abbreviation used: SLS, standard linear solid; SLL, standard linear liquid.

\section{Acknowledgements}

We thank Atef Asnacios and Kalpana Mandal for stimulating discussions. C.A is funded by a grant from UPMC University Paris 6 (Programme Doctoral "Interfaces Pour le Vivant"). We acknowledge funding from INCa/Cancéropôle (\#2013-1-PL BIO-07-ICR-1). We thank the reviewers for their constructive comments. We apologize to colleagues whose work we could not cite due to space limitations. The authors declare no conflict of interest. 


\begin{tabular}{|c|c|c|c|c|c|c|c|c|}
\hline \multirow{2}{*}{$\begin{array}{l}\text { Rheological } \\
\text { technique }\end{array}$} & \multirow[t]{2}{*}{ reference } & \multirow[t]{2}{*}{ Cell lines } & \multicolumn{4}{|c|}{ Parameters studied } & \multirow[t]{2}{*}{ model } & \multirow{2}{*}{$\begin{array}{c}\text { Element of the cytoskeleton } \\
\text { studied }\end{array}$} \\
\hline & & & $\mathrm{E}(\mathrm{kPa})$ & $\mathrm{K}(\mathbf{P a})$ & $\mu$ (Pa.s) & Other & & \\
\hline \multirow[t]{2}{*}{$\begin{array}{l}\text { Aspiration } \\
\text { pipette }\end{array}$} & $\begin{array}{l}\text { Pachenari et al., } \\
2014\end{array}$ & $\begin{array}{l}\text { Human colon cancer cells: } \\
\text { HT29 (grade I) } \\
\text { SW48 (grade IV) }\end{array}$ & & $\begin{array}{l}\mathrm{K}_{1, \mathrm{HT29}}=80 \\
\mathrm{~K}_{1, \mathrm{SW} 48}=60 \\
\mathrm{~K}_{1, \mathrm{HT29}}=150 \\
\mathrm{~K}_{2, \mathrm{SW} 48}=350\end{array}$ & $\begin{array}{l}\mu_{\mathrm{HT} 29}=7000 \\
\mu_{\mathrm{SW} 48}=6000\end{array}$ & $\begin{array}{l}\text { - time constant } \tau \\
\text { - deformability rate }\end{array}$ & SLS & $\begin{array}{l}\text { Organization of actin } \\
\text { cytoskeleton } \\
\text { Levels of actin and } \\
\text { microtubule }\end{array}$ \\
\hline & $\begin{array}{l}\text { Thoumine et } \\
\text { al., } 1997\end{array}$ & $\begin{array}{l}\text { human fibroblast : } \\
\text { normal AS3 } \\
\text { SV-40 transformed fibroblast: } \\
\text { AS3WT2 }\end{array}$ & & & $\begin{array}{l}\mu_{\mathrm{AS} 3}=1.1510^{4} \\
\mu_{\mathrm{AS} 3 \mathrm{WT2} 2}= \\
0.810^{4}\end{array}$ & & & \\
\hline \multirow[t]{2}{*}{$\begin{array}{l}\text { Particle } \\
\text { tracking }\end{array}$} & Li et al., 2009 & $\begin{array}{l}\text { Human breast cells : } \\
\text { MCF10A (non-malignant) } \\
\text { MCF } 7 \text { (malignant) } \\
\text { Human pancreas cells : } \\
\text { PA-T (non-malignant) } \\
\text { PA-S (malignant) }\end{array}$ & $\begin{array}{l}\text { Young modulus at } 1 \mathrm{~Hz}: \\
\mathrm{E}^{*} \mathrm{MCF} 10 \mathrm{~A}=6 \\
\mathrm{E}^{*}{ }_{\mathrm{MCF} 7}=0,3\end{array}$ & & & $\begin{array}{l}\text { MSD }_{\text {tumor cells }} \text { larger } \\
\text { than MSD begnin cells }\end{array}$ & $\begin{array}{l}\text { Modified Hertz } \\
\text { model }\end{array}$ & \\
\hline & $\begin{array}{l}\text { Agus et al., } \\
2013\end{array}$ & $\begin{array}{l}\text { Human breast cells: } \\
\text { MCF10A } \\
\text { MDA-MB-231 (tumorigenic) }\end{array}$ & $\begin{array}{l}\text { Young modulus (depth of } \\
0.8 \mu \mathrm{m} \text { at lamella) } \\
E_{\text {MCF-10A }}=1.75 \\
E_{\text {MDA-MB-231 }}=0.3\end{array}$ & & & $\begin{array}{l}\text { MSD } \\
\text { MSDA-MB-231 above } \\
\text { MSCF } 10 \mathrm{~A}\end{array}$ & Hertz model & \\
\hline & $\begin{array}{l}\text { Park et al., } \\
2005^{*}\end{array}$ & $\begin{array}{l}\text { normal fibroblast : } \\
\text { BALB 3T3 } \\
\text { malignantly transformed fibroblast: } \\
\text { SV-T2, H-ras }\end{array}$ & $\begin{array}{l}\text { Elastic constant at the } \\
\text { leading edge: } \\
\mathrm{E}_{\mathrm{BALB} 3 \mathrm{T3}}=1.01 \pm 0.40 \\
\mathrm{E}_{\mathrm{SV}-\mathrm{T} 2}=0.48 \pm 0.51 \\
\mathrm{E}_{\text {Hras }}=0.42 \pm 0.35 \\
\end{array}$ & & & & $\begin{array}{l}\text { According to } \\
\text { the region, } \\
\text { Hertz } \\
\text { model or Chen } \\
\text { model }\end{array}$ & $\begin{array}{l}\text { Actin density } \\
\text { Motility of lamellipode }\end{array}$ \\
\hline & $\begin{array}{l}\text { Ketene } e t \\
\text { al.,2012* }\end{array}$ & $\begin{array}{l}\text { Mouse ovarian surface epithelial: } \\
\text { Early(E) : 15-25 passages } \\
\text { Intermediate(I) : } 75-80 \text { passages } \\
\text { Late(L) }: 155-171 \text { passages }\end{array}$ & $\begin{array}{l}\text { Young modulus: } \\
\mathrm{E}_{\mathrm{E}}=0.554 \pm 0.349 \\
\mathrm{E}_{\mathrm{I}}=0.472 \pm 0.306 \\
\mathrm{E}_{\mathrm{L}}=0.395 \pm 0.136\end{array}$ & $\begin{array}{l}\mathrm{K}_{1, \mathrm{E}}=371 \pm 229 \\
\mathrm{~K}_{1, \mathrm{I}}=310 \pm 220 \\
\mathrm{~K}_{1, \mathrm{~L}}=261 \pm 90 \\
\mathrm{~K}_{2, \mathrm{E}}=117.5 \pm 85 \\
\mathrm{~K}_{2, \mathrm{I}}=73.36 \pm 65 \\
\mathrm{~K}_{2, \mathrm{~L}}=49.14 \pm 31\end{array}$ & $\begin{array}{l}\mu_{\mathrm{E}}=145 \pm 102 \\
\mu_{\mathrm{I}}=103 \pm 54 \\
\mu_{\mathrm{L}}=51 \pm 30\end{array}$ & $\begin{array}{l}\text { - time constant } \tau \\
- \text { Eelassic, }_{\text {relaxed, }} \\
\text { Einstantaneous }\end{array}$ & $\begin{array}{l}\text { Hertz model } \\
\text { SLS }\end{array}$ & Actin organization \\
\hline & $\begin{array}{l}\text { Rother } \text { et al., } \\
2014\end{array}$ & $\begin{array}{l}\text { Cells lines from different localizations : Kidney } \\
\text { (K), adrenal gland (AG), lung epithelial layer } \\
\text { (L), mammary gland (MG) } \\
\text { Begnin : } \\
\text { MDCKII (K), NMuMG(MG), MCF-10A(MG), } \\
\text { NIH3T3 } \\
\text { Malign: } \\
\text { CaKi-1 (K); MDA-MB-231(MG); MCF-7; } \\
\text { A549(L); SW13 (AG). }\end{array}$ & & & $\begin{array}{l}\mu_{\text {begnin }}= \\
4.65 \pm 0.28 \\
\mu_{\text {malign }} \\
=5.60 \pm 0.18\end{array}$ & $\begin{array}{l}\text {-Shear modulus } \\
\mathrm{G}_{\text {begin }}=1.28 \pm 0.1 \\
\mathrm{G}_{\text {malign }}=0.62 \pm 0.07 \\
\text {-loss tangent } \\
\boldsymbol{\eta}=\mathrm{G} \text { '"/G' } \\
\text { Higher for malign } \\
\text { cells }\end{array}$ & $\begin{array}{l}\text { power-law } \\
\text { structural } \\
\text { damping } \\
\text { model }\end{array}$ & \\
\hline & $\begin{array}{l}\text { Darling et al, } \\
2007^{*}\end{array}$ & $\begin{array}{l}\text { Chondrosarcomas of grade II: } \\
\text { 105KC (no metastasize) } \\
\text { FS090 (less aggressive than JJ012) } \\
\text { JJ012 (highest malignancy) }\end{array}$ & $\begin{array}{l}\text { Young modulus: } \\
\mathrm{E}_{105 \mathrm{KC}}=0.800 \\
\mathrm{E}_{\mathrm{FS} 090}=1.27 \\
\mathrm{E}_{\mathrm{JJ} 012}=0.480\end{array}$ & 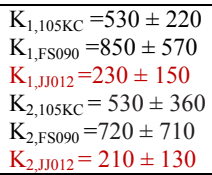 & & time constant $\tau$ & $\begin{array}{l}\text { Hertz model } \\
\text { SLS }\end{array}$ & Actin fibers \\
\hline & $\begin{array}{l}\text { Cross et al., } \\
2007\end{array}$ & $\begin{array}{l}\text { Pleural fluid of seven patients with suspected } \\
\text { adenocarcinomes : } \\
\text { After analysis : } \\
3 \text { normal cells from liver, hepatic and oedema } \\
4 \text { cancer cells from lung, breast and pancreas }\end{array}$ & $\begin{array}{l}\text { Young modulus: } \\
\mathrm{E}_{\text {normal }}=1.970 \\
\mathrm{E}_{\text {cancer }}=0.530\end{array}$ & & & & Hertz model & \\
\hline & $\begin{array}{l}\text { Plodinec et al., } \\
2012\end{array}$ & $\begin{array}{l}\text { Mice lung primary cells: } \\
\text { Cells from primary tumor }\end{array}$ & $\begin{array}{l}\text { Stiffness } \\
1.26+0.43 \\
\end{array}$ & & & & & \\
\hline
\end{tabular}




\begin{tabular}{|c|c|c|c|c|c|c|c|c|}
\hline & & $\begin{array}{l}\text { Metastatic cells } \\
\text { Mouse mammary gland primary cells: } \\
\text { Normal and early cancer cells }\end{array}$ & $\begin{array}{l}0.56+0.26 \\
1.02+0.42 \\
0.45+0.12\end{array}$ & & & & & \\
\hline \multirow{11}{*}{$\begin{array}{c}\text { Rheological } \\
\text { technique }\end{array}$} & \multirow[t]{2}{*}{ reference } & \multirow[t]{2}{*}{ Cell lines } & \multicolumn{4}{|c|}{ Parameters studied } & \multirow[t]{2}{*}{ model } & \multirow[t]{2}{*}{ Element of the cytoskeleton studied } \\
\hline & & & $\begin{array}{c}\mathbf{E} \\
(\mathbf{k P a})\end{array}$ & $\begin{array}{c}\mathrm{K} \\
(\mathbf{P a})\end{array}$ & $\begin{array}{c}\eta \\
(\text { Pa.s) }\end{array}$ & Other & & \\
\hline & $\begin{array}{l}\text { Lekka et al, } \\
1999\end{array}$ & $\begin{array}{l}\text { Human epithelial cells } \\
\text { Non-malignant : Hu609 (ureter) HCV29 ( } \\
\text { bladder urothelium) } \\
\text { Cancer : } \\
\text { Hu456 (bladder carcinoma) } \\
\text { T24 (bladder carcinoma) } \\
\text { BC3726 (v-ras transformed HCV29) }\end{array}$ & $\begin{array}{l}\text { Young modulus: } \\
\mathrm{E}_{\mathrm{H} 4609}=12.9 \pm 4.8 \\
\mathrm{E}_{\mathrm{HCV} 29}=10.0 \pm 4.6 \\
\mathrm{E}_{\mathrm{H} 4456}=0.4 \pm 0.3 \\
\mathrm{E}_{\mathrm{T} 24}=1.0 \pm 0.5 \\
\mathrm{E}_{\mathrm{BC} 3226}=1.4 \pm 0.7\end{array}$ & & & & Sneddon's model & \\
\hline & $\begin{array}{l}\text { Grady et al., } \\
2016^{*}\end{array}$ & $\begin{array}{l}\text { normal cells: } \\
\text { Dermal fibroblasts } \\
\text { Boval chondrocytes } \\
\text { HUVEC } \\
\text { Cancer cells: } \\
\text { Fibrosarcoma } \\
\text { hepatocellular carcinoma }\end{array}$ & $\begin{array}{l}\text { Elastic modulus } \\
\text { Normal } \\
E_{\text {HUVEC }}=1.37 \\
E_{\text {Chondrocyte }}=2.07 \\
E_{\text {Fibroblast }}=2.19 \\
E_{\text {Fibrosarcoma }}=0.48 \\
E_{\text {Carcinoma }}=0.30\end{array}$ & & & & Hertz model & $\begin{array}{l}\text { Actin and microtubules } \\
\text { polymerization (nocodazole and } \\
\text { cytochalasin D) }\end{array}$ \\
\hline & $\begin{array}{l}\text { Omidvar et al., } \\
2014^{*}\end{array}$ & $\begin{array}{l}\text { Human breast cancer cells: } \\
\text { MCF-7 } \\
\text { T47D } \\
\text { MDA-MB-231 }\end{array}$ & $\begin{array}{l}\text { Young modulus } \\
\mathrm{E}_{\text {MCF- }}=1.04 \pm 0.27 \\
\mathrm{E}_{\text {T47D }}=0.94 \pm 0.25 \\
\mathrm{E}_{\text {MDA-MB-231 }}=0.62 \pm 0.21\end{array}$ & & & $\begin{array}{l}\text { Cell-cell detachment force }(\mathrm{nN}) \\
\mathrm{F}_{\mathrm{MCF}-7}=13.5 \pm 2.3 \\
\mathrm{~F}_{\mathrm{T} 47 \mathrm{D}}=5.8 \pm 0.6 \\
\mathrm{~F}_{\mathrm{MDA}-\mathrm{MB}-231}=4.6 \pm 0.6\end{array}$ & Hertz model & $\begin{array}{l}\text { Expression of N-cadherin and E-cadh } \\
\text { Actin distribution }\end{array}$ \\
\hline & Xu et al., 2012* & $\begin{array}{l}\text { Ovarian normal cells }: \text { IOSE } \\
\text { Ovarian cancer cells: HEY } \\
\text { HEY A8 (highly) } \\
\text { OVCAR3 } \\
\text { OVCAR4 }\end{array}$ & $\begin{array}{l}\text { Young modulus } \\
\text { ElOSE }^{\text {IOS }}=2.472 \pm 2.048 \\
\text { E HEY }=0.884 \pm 0.529 \\
E_{\text {HEYA8 }}=0.494 \pm 0.222 \\
E_{\text {OVCAR3 }}=0.576 \pm 0.236 \\
E_{\text {OVCAR4 }}=1.120 \pm 0.865\end{array}$ & & & & Hertz model & $\begin{array}{l}\text { Actin distribution (density and } \\
\text { alignement of fibers) }\end{array}$ \\
\hline & $\begin{array}{l}\text { Prabhune } \text { et al., } \\
2012\end{array}$ & $\begin{array}{l}\text { Primary thyroid cells } \\
\text { normal cells : S748 (1 donor) } \\
\text { cancer cells : S277 (1 donor) }\end{array}$ & $\begin{array}{l}\text { Elastic modulus } \\
\text { E }_{\mathrm{S} 748}=[2,2-6,9] \\
\mathrm{E}_{\mathrm{S} 277}=[1,2-1,4]\end{array}$ & & & $\begin{array}{l}\text { Looked at } \mathrm{E} \text { on three consecutive } \\
\text { days of culture }\end{array}$ & $\begin{array}{l}\text { Hertz-Sneddon } \\
\text { model }\end{array}$ & Actin distribution \\
\hline & $\begin{array}{l}\text { Bastatas et al., } \\
2012\end{array}$ & $\begin{array}{l}\text { Prostate cancer cells: } \\
\text { LNCaP (lowly metastatic, non-metastatic) } \\
\text { CL-1, CL-2 (highly metastatic) }\end{array}$ & $\begin{array}{l}\text { Elastic modulus } \\
\mathrm{E}_{\mathrm{S} 748} \sim 200 \\
\mathrm{E}_{\mathrm{CL}-1} \sim 400 \\
\mathrm{E}_{\mathrm{CL}-2} \sim 260 \\
\end{array}$ & & & $\begin{array}{l}\text { Cell migration } \\
{\left[\mathrm{Ca}^{2+}\right]_{\text {in dynamics }}}\end{array}$ & $\begin{array}{l}\text { According to the } \\
\text { region, Hertz } \\
\text { model or Chen } \\
\text { model }\end{array}$ & \\
\hline & $\begin{array}{l}\text { Faria et al., } \\
2008\end{array}$ & $\begin{array}{l}\text { Benign prostate cells: BPH } \\
\text { Malignant prostate cells: } \\
\text { LNCaP clone FGC (non invasive) } \\
\text { PC-3 (hihgly invasive) }\end{array}$ & $\begin{array}{l}\text { Young modulus } \\
E_{\text {BPH }}=2.8 \pm 0.5 \\
E_{\text {LNCaP }}=0.3 \pm 0.05 \\
E_{\text {PC. } 3}=1.4 \pm 0.2\end{array}$ & & & & Hertz model & \\
\hline & $\begin{array}{l}\text { Ramos et al., } \\
2014\end{array}$ & $\begin{array}{l}\text { Bladder cells : } \\
\text { Non-cancerous : HCV29 } \\
\text { Cancer : T24 transitional cell carcinoma) } \\
\text { HTB-9 (grade II, carcinoma) } \\
\text { HT1376 (grade III, carcinoma) }\end{array}$ & $\begin{array}{l}\text { Young modulus (biggest } \\
\text { peak) } \\
\mathrm{E}_{\text {HCV29 }}=16.0 \pm 0.9 \\
\mathrm{E}_{\text {HTB }-9}=3.0 \pm 0.1 \\
\mathrm{E}_{\text {T24 }}=2.9 \pm 0.5 \\
\mathrm{E}_{\text {HT-1376 }}=5.2 \pm 0.1\end{array}$ & & & & Sneddon's model & $\begin{array}{l}\text { Different studies on actin inside cell } \\
\text { lines: } \\
\text { (presence of stress fiber, F-actin } \\
\text { expression levels, effect of actin } \\
\text { polymerization with cytochalasin D) }\end{array}$ \\
\hline & $\begin{array}{l}\text { Abidine et al., } \\
2015\end{array}$ & $\begin{array}{l}\text { Bladder cells : } \\
\text { RT112 moderately differentiated } \\
\text { T24 higher malignancy potential } \\
\text { J82 higher malignancy potential }\end{array}$ & & & & $\begin{array}{l}\text { transition frequency } \mathrm{f} \text { in } \\
\text { perinucleus region (crossing of } \\
\mathrm{G}^{6} \text { et } \mathrm{G}^{\prime} \text { ') in } \mathrm{Hz} \\
\mathrm{f}_{\mathrm{RT} 1122}=160 \pm 15\end{array}$ & Hertz model & $\begin{array}{l}\text { Actin polymerization (latrunculin A } \\
\text { and Y27632) }\end{array}$ \\
\hline
\end{tabular}




\begin{tabular}{|c|c|c|c|c|c|c|c|c|}
\hline & & & & & & $\begin{array}{l}\mathrm{f}_{\mathrm{T}_{224}}=150 \pm 15 \\
\mathrm{f}_{\mathrm{J} 82}=205 \pm 20 \\
\text { Plateau modulus at low frequency } \\
\text { at perinucleus region in Pa } \\
\mathrm{G}_{\mathrm{RT112}}^{0}=2756 \pm 102 \\
\mathrm{G}^{0}{ }_{\mathrm{T} 24}=1856 \pm 120 \\
\mathrm{G}_{\mathrm{J82}}^{0}=1350 \pm 45 \\
\end{array}$ & & \\
\hline \multirow{2}{*}{$\begin{array}{l}\text { Rheological } \\
\text { technique }\end{array}$} & \multirow[t]{2}{*}{ reference } & \multirow[t]{2}{*}{ Cell lines } & \multicolumn{4}{|c|}{ Parameters studied } & \multirow[t]{2}{*}{ model } & \multirow[t]{2}{*}{ Element of the cytoskeleton studied } \\
\hline & & & $\mathbf{E}(\mathrm{kPa})$ & $\mathbf{K}(\mathbf{P a})$ & $\begin{array}{c}\text { Mu } \\
(\text { Pa.s) }\end{array}$ & Other & & \\
\hline $\begin{array}{l}\text { Optical } \\
\text { stretcher }\end{array}$ & $\begin{array}{l}\text { Guck et al., } \\
2005\end{array}$ & $\begin{array}{l}\text { Human breast cells: } \\
\text { MCF10 } \\
\text { MCF7 } \\
\text { modMCF7 } \\
\text { MDA-MB-231, modMDA-MB-231 } \\
\text { Fibroblast : } \\
\text { BALB 3T3 } \\
\text { SV-T2 } \\
\end{array}$ & & & & $\begin{array}{l}\text { Optical deformability (\%): } \\
\mathrm{OD}_{\text {MCF-10 }}=10.5 \pm 0.8 \\
\mathrm{OD}_{\text {MCF- }}=21.4 \pm 1.1 \\
\mathrm{OD}_{\text {modMCF-7 }}=30.4 \pm 1.8 \\
\mathrm{OD}_{\text {MDA }}=33.7 \pm 1.4 \\
\mathrm{OD}_{\text {modMDA }}=24.4 \pm 2.5 \\
\mathrm{OD}_{\text {BALB/3 }}=8.4 \pm 1.0 \\
\mathrm{OD}_{\mathrm{SV}-\mathrm{T2}}=11.7 \pm 1.1 \\
\end{array}$ & & \\
\hline & $\begin{array}{l}\text { Remmerbach et } \\
\text { al., } 2009\end{array}$ & $\begin{array}{l}\text { Primary oral cancer cells : } \\
\text { Normal (PHK) : } 4 \text { donnors } \\
\text { cancer (OSCCs): } 5 \text { patients } \\
\text { Oral cell lines : } \\
\text { Normal :OKF-4TERT1, OKF-6TERT1 } \\
\text { Cancer :HN, BHY, CAL-27, CAL-33 }\end{array}$ & & & & $\begin{array}{l}\text { Compliance } \mathrm{J}\left(\mathrm{Pa}^{-1}\right) \text { at } \mathrm{t}=0.5 \mathrm{sec} \\
\mathrm{J}_{\text {all normal lines }}=7.18 \pm 0.43 \\
\mathrm{~J}_{\text {all cancer lines }}=18.2 \pm 1.1\end{array}$ & & \\
\hline & $\begin{array}{l}\text { Wottawah et } \\
\text { al., } 2005\end{array}$ & $\begin{array}{l}\text { normal fibroblast : } \\
\text { NIH/3T3 } \\
\text { malignantly transformed fibroblast: } \\
\text { SV-T2 }\end{array}$ & & & & $\begin{array}{l}\mathrm{G}^{\prime}{ }_{\mathrm{NH}-3 \mathrm{T3}}=100 \pm 10 \mathrm{~Pa} \\
\mathrm{G}^{\prime}{ }_{\mathrm{SV}-\mathrm{T} 2}=63 \pm 7 \mathrm{~Pa}\end{array}$ & & $\begin{array}{l}\text { Reduced actin cytoskeleton for SV- } \\
\text { T2 }\end{array}$ \\
\hline $\begin{array}{l}\text { Optical } \\
\text { tweezers }\end{array}$ & Guo et al., 2014 & $\begin{array}{l}\text { Human breast cells: } \\
\text { MCF10-A } \\
\text { MCF-7 }\end{array}$ & & & & $\begin{array}{l}\text { MSD }_{\text {MCF- }} \text { above } \\
\text { MSD }_{\text {MCF-10A }}\end{array}$ & $\begin{array}{l}\text { No model } \\
\text { Found power law }\end{array}$ & Inhibition of Myosin II \\
\hline & $\begin{array}{l}\text { Bertseva et al., } \\
2012\end{array}$ & $\begin{array}{l}\text { Bladder cells } \\
\text { Non-cancerous : HCV29 } \\
\text { Cancer : T24 }\end{array}$ & & & & $\begin{array}{l}\text { MSD }_{\text {T24 above }} \\
\text { MSD }_{\text {HCV29 }}\end{array}$ & Found power law & \\
\hline $\begin{array}{l}\text { pptical } \\
\text { tweezers + } \\
\text { micropatterns }\end{array}$ & $\begin{array}{l}\text { Mandal et al., } \\
2016\end{array}$ & $\begin{array}{l}\text { Human breast cells: } \\
\text { MCF10-A } \\
\text { MDA-MB-231 }\end{array}$ & & & & $\begin{array}{l}\text { Shear modulus }(\mathrm{Pa}) \\
\mathrm{G}_{\mathrm{MFF}-10}=3.6 \\
\mathrm{G}_{\mathrm{MDD}}=1.6\end{array}$ & SLL & $\begin{array}{l}\text { Microtubules } \\
\text { Actin }\end{array}$ \\
\hline Microfluidics & Hou et al., 2009 & $\begin{array}{l}\text { Human breast cells : } \\
\text { MCF10A } \\
\text { MCF } 7\end{array}$ & & & & $\begin{array}{l}\text { Entry time } \\
\text { Elongation } \\
\text { Transit velocity } \\
\end{array}$ & & \\
\hline Magnetic & $\begin{array}{l}\text { Swaminathan et } \\
\text { al., } 2011\end{array}$ & $\begin{array}{l}\text { Primary ovarian cancer cells from ascites: } \\
\text { OV445 (least invasive III), } \\
\text { OV207 (most invasive IV), } \\
\text { Ovarian cancer cell lines: } \\
\text { IGROV (less inv --) } \\
\text { Ovca420 (+/-) } \\
\text { HEY (most inv }++), \text { SKOV3 }(++)\end{array}$ & & & & $\begin{array}{l}\text { Max compliance } \mathrm{J}\left(\mathrm{Pa}^{-1}\right) \\
\mathrm{J}_{\mathrm{IGROV}}=0.25 \\
\mathrm{~J}_{\text {Ovca420 }}=0.45 \\
\mathrm{~J}_{\mathrm{HEY}}=1 \\
\mathrm{~J}_{\mathrm{SKOV} 3}=1 \\
\mathrm{~J}_{207}=3.2 \\
\mathrm{~J}_{445}=0.2\end{array}$ & Jeffrey's model & $\begin{array}{l}\text { Actin distribution } \\
\text { Presence of phosphorylated myosin } \\
\text { light chain (pMLC) } \\
\text { Expression of E-Cadherin and } \\
\text { Vimentin } \\
\text { Inhibition of Myosin II }\end{array}$ \\
\hline $\begin{array}{l}\text { Acoustic } \\
\text { wave }\end{array}$ & $\begin{array}{l}\text { Hartono et al., } \\
2011\end{array}$ & $\begin{array}{l}\text { Normal cells: } \\
\text { breast }=3.77 \pm 0.09 \\
\text { fibroblast }=3.78 \pm 0.17\end{array}$ & & & & $\begin{array}{l}\text { Compressibility }\left(\mathrm{x}^{1} 0^{-10} \mathrm{~Pa}^{-1}\right): \\
\mathrm{C}_{\text {breast }}=3.77 \pm 0.09 \\
\mathrm{C}_{\text {fibroblast }}=3.78 \pm 0.17\end{array}$ & & \\
\hline
\end{tabular}




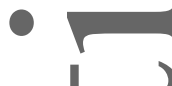

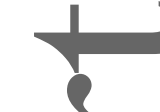

Z

\%

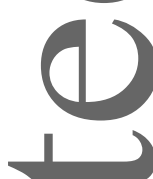

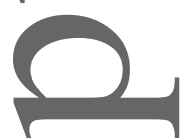

(1)

U 